\title{
Novel triazolothiadiazines act as potent anticancer agents in liver cancer cells through Akt and ASK-1 proteins
}

\author{
Peri S. Aytaç ${ }^{\mathrm{a}, \dagger}$, Irem Durmaz ${ }^{\mathrm{b}, \dagger}$, Douglas R. Houston ${ }^{\mathrm{c}}$, Rengül Çetin-Atalay ${ }^{\mathrm{d}, *}$, Birsen Tozkoparan ${ }^{\mathrm{a}, *}$ \\ a Department of Pharmaceutical Chemistry, Faculty of Pharmacy, Hacettepe University, Sihhiye, 06100 Ankara, Turkey \\ ${ }^{\mathrm{b}}$ Department of Molecular Biology and Genetics, Bilkent University, 06800 Ankara, Turkey \\ ${ }^{\mathrm{c}}$ Institute of Structural and Molecular Biology, University of Edinburgh, EH9 3JG, UK \\ ${ }^{\mathrm{d}}$ Cancer Systems Biology Laboratory, Department of Medical Informatics, Graduate School of Informatics, ODTU, 06800 Ankara, Turkey
}

\section{A R T I C L E I N F O}

\section{Article history:}

Received 21 August 2015

Revised 6 January 2016

Accepted 7 January 2016

Available online 8 January 2016

\section{Keywords:}

Aminomercaptotriazole

Triazolothiadiazine

Cytotoxic activity

Apoptosis

Oxidative stress

\begin{abstract}
A B S T R A C T
Newly designed triazolothiadiazines incorporating with structural motifs of nonsteroidal analgesic antiinflammatory drugs were synthesized and screened for their bioactivity against epithelial cancer cells. Compounds with bioactivities less then $\sim 5 \mu \mathrm{M}\left(\mathrm{IC}_{50}\right)$ were further analyzed and showed to induce apoptotic cell death and SubG ${ }_{1}$ cell cycle arrest in liver cancer cells. Among this group, two compounds ( $\mathbf{1 g}$ and 1h) were then studied to identify the mechanism of action. These molecules triggered oxidative stress induced apoptosis through ASK-1 protein activation and Akt protein inhibition as demonstrated by downstream targets such as GSK3 $\beta, \beta$-catenin and cyclin D1. QSAR and molecular docking models provide insight into the mechanism of inhibition and indicate the optimal direction of future synthetic efforts. Furthermore, molecular docking results were confirmed with in vitro COX bioactivity studies. This study demonstrates that the novel triazolothiadiazine derivatives are promising drug candidates for epithelial cancers, especially liver cancer.
\end{abstract}

(C) 2016 Published by Elsevier Ltd.

\section{Introduction}

Cancer related deaths are growing at a faster rate than expected despite the improvements in early detection and advanced treatment strategies, including radical surgery along with chemotherapy and radiotherapy. According to World Health Organization (WHO) data, cancer is recently ranked primary cause of death replacing cardiovascular diseases throughout the world. ${ }^{1}$ Chemotherapy is employed as a crucial part of the multimodal treatment of cancer when surgery is not suitable. However, poor cytotoxic efficacy, severe dose-limiting toxicity and resistance resourcing from various factors restrict the chemotherapeutic responses of available drugs. Therefore, discovery of efficient cytotoxic agents with improved selectivity against cancer is still an attractive field. ${ }^{2}$

As an innovative approach in drug design, some common nonsteroidal anti-inflammatory drugs (NSAIDs) (aspirin, ibuprofen, naproxen, meloxicam, celecoxib, etc.) have been repurposed for anticancer drug research. ${ }^{3-7}$ There are noteworthy studies claim

\footnotetext{
* Corresponding authors. Tel.: +90 3122107887 (R.C.-A.), +90 3123053020 (B.T.).

E-mail addresses: rengul@metu.edu.tr (R. Çetin-Atalay), tbirsen@hacettepe.edu.tr (B. Tozkoparan).

Equal contribution.
}

that these agents exhibit anticancer activity through COX-dependent or independent pathways., ${ }^{3,7-11}$ Experimental studies and clinical observations on individuals taking regular and long-term NSAIDs showed a reduced risk of cancer incidence., ${ }^{2,3,12-14}$ Additionally, conventional NSAIDs and selective COX-2 inhibitors have been reported to possess cancer chemopreventive effects or lower carcinogenesis risk. ${ }^{2-4,8,13,14}$ However, insufficient risk-benefit consideration, failure of dose-treatment time determination and unclear safety profiles limit the use of NSAIDs in cancer chemoprevention. $^{13}$

The synthesis and analgesic/anti-inflammatory evaluation of various condensed heterocyclic systems derived from 1,2,4-triazole-5-thiones have been discussed within our extensive research program for fifteen years. ${ }^{15-21}$ Lately, we have focused on triazolothiadiazine and triazolothiadiazole scaffolds ${ }^{22-24}$, known to have significant biological activities. ${ }^{25}$ In recent years, these scaffolds have attracted attention because of their cytotoxic effects. ${ }^{26-33}$ This considerable background has directed us to investigate the anticancer effect of our compounds bearing a triazolothiadiazine core. ${ }^{34}$ The encouraging results we obtained, and the impressive history of NSAIDs in the cancer research field, have inspired us to design new hybrid compounds by combining a 1,2,4-triazolo[3,4-b]-1,3,4-thiadiazine ring with the commercially available NSAIDs, ibuprofen, naproxen and flurbiprofen, that are expected to have enhanced anticancer activity. 
In this study the bioactivities of novel triazolothiadiazines were tested initially on epithelial cancer cells, then the mechanism of action was examined with liver cancer cells. Hepatocellular carcinoma (HCC) is among the most-deadly cancers according to the World Cancer Report 2014. ${ }^{1}$ Percutaneous ablation and transplantation surgery are treatment options for early tumors, however, advanced tumors usually acquire palliative therapy. ${ }^{35-37}$ Limited treatment options and resistance to conventional chemotherapy and radiotherapy ${ }^{35}$ made vital novel targeted therapeutic agent development for treatment of HCC. Herein, we demonstrate the putative in vitro anticancer properties of our newly designed triazolothiadiazines as well as the death mechanism they trigger in liver cancer cells.

\section{Results and discussion}

\subsection{Chemistry}

4-Amino-1,2,4-triazole-5-thiones (1-3) and 1,2,4-triazolo[3,4$b]$-1,3,4-thiadiazines ( $\mathbf{1} \mathbf{a}-\mathbf{3 j}$ ) were acquired according to the pathway that was reported in our previous articles ${ }^{22,23}$ as illustrated in Scheme 1. Briefly, aminomercaptotriazoles (1-3) derived from NSAIDs were obtained by fusing the traditionally available drugs (ibuprofen, naproxen or flurbiprofen) carrying an aliphatic carboxylic acid group, with thiocarbohydrazide at its melting point $\left(\sim 170^{\circ} \mathrm{C}\right)$. The title compounds, triazolothiadiazines, were achieved from a one-pot synthesis of compounds 1-3 and corresponding 2-bromo/2-chloro-substituted acetophenones in anhydrous ethanol under reflux. As a time-saving option, they were also obtained by microwave-promoted synthesis with less ballast product.

All compounds were characterized by their melting points, elementary analysis, infrared, ${ }^{1} \mathrm{H}$ NMR and mass spectra. The spectral data matched the proposed structures. Although compounds 1-3 have been reported by Metwally et al., ${ }^{38}$ their reported melting points did not match our data. Therefore, we performed all the characterization assays once again for compounds 1-3. In the IR spectra of compounds 1-3, vibrations appeared at 1167$1153 \mathrm{~cm}^{-1}$, which corresponded to $\mathrm{C}=\mathrm{S}$ stretching bands, and absence of stretching bands at about $2700-2500 \mathrm{~cm}^{-1}$, attributable to an $\mathrm{S}-\mathrm{H}$ bond, which revealed that compounds 1-3 are present in thione form in the solid state. The disappearance of the bands subjected to $\mathrm{N}-\mathrm{H}$ and $\mathrm{C}=\mathrm{S}$ in the IR spectra of the resulting compounds have confirmed a thiadiazine ring closure.

In the ${ }^{1} \mathrm{H}$ NMR spectra, $-\mathrm{SCH}_{2}$ protons were split into two doublets, while we expected a singlet peak. So we recorded a NOESY
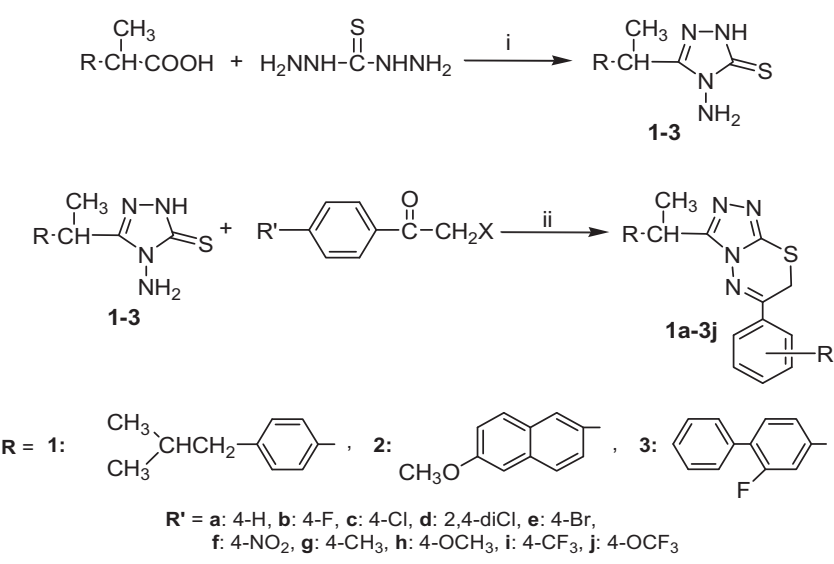

Scheme 1. Synthetic pathways of the compounds 1-3 and 1a-3j. Reagents and conditions: (i): heat $\left(\sim 170^{\circ} \mathrm{C}\right)$, (ii): abs. ethanol, reflux or ethanol/microwave energy. spectrum of compound 1a to clarify the doublet signals of the $\mathrm{SCH}_{2}$ protons, and saw that geminal protons caused two independent doublet splittings according to an $\mathrm{AB}$ spin system.

The mass fragmentation of the compounds was studied under electron spray ionization (ESI). The peaks of quasimolecular ions $\left[\mathrm{M}^{+}+\mathrm{H}\right]$ or $\left[\mathrm{M}^{+}+\mathrm{Na}\right]$, which appeared at different intensities, confirmed the molecular weights of the examined compounds.

Analytically pure samples were subjected to cytotoxic evaluation.

\subsection{Pharmacology}

\subsubsection{Cytotoxic evaluation of synthesized compounds with an NCI-SRB assay ${ }^{39}$}

We first assessed all synthetic derivatives (aminomercaptotriazoles (1-3), 1,2,4-triazolo[3,4-b]-1,3,4-thiadiazines (1a-3j)) and commercially available NSAIDs (ibuprofen, naproxen and flurbiprofen) for their cytotoxic activities against liver (Huh7), breast (MCF7) and colon (HCT116) human cancer cell lines in vitro. Campthotecin (CPT, a DNA topoisomerase inhibitor) was chosen as a positive control and DMSO as a negative vehicle control for the cytotoxic effect. The cells were treated with the compounds in increasing concentrations $(2.5-40 \mu \mathrm{M})$ and their IC $_{50}$ values were calculated. All triazolothiadiazine derivatives (1a-3j) inhibited cell proliferation with $\mathrm{IC}_{50}$ values in the range of 1.1-18.8 $\mu \mathrm{M}$, as shown in Table 1 , neither NSAIDs nor starting compounds (1-3) showed significant cytotoxic effects in the preliminary screening. Therefore, we could propose an initial structure-activity relationship conclusion that fusing a 1,2,4-triazole ring with a thiadiazine is essential for cytotoxic activity. Numerous compounds bearing ibuprofen $(\mathbf{1} \mathbf{a}-\mathbf{j})$ or flurbiprofen $(\mathbf{3 a} \mathbf{a}-\mathbf{j})$ residues at the third position of the triazolothiadiazine core demonstrated significant cytotoxicity with preferential activity against the Huh7 cell line when compared to the naproxen $(\mathbf{2} \mathbf{a}-\mathbf{j})$ counterpart. Nonetheless, varying substituents on the phenyl ring at the sixth position of the triazolothiadiazine core did not dramatically change the cytotoxic strength of the compounds. Even though it is hard to draw an overall SAR conclusion related to these results, some generalizations can be established (further detailed QSAR analysis given below):

Ibuprofen compounds carrying an electron-donating group (4-methyl (19), 4-methoxy (1h) and 4-trifluoromethoxy (1j)) and flurbiprofen compounds carrying an electron withdrawing group (4-fluoro (3b), 4-chloro (3c), 2,4-dichloro (3d), 4-bromo (3e) and 4-nitro (3f)) attached to the phenyl ring at the sixth position of the triazolothiadiazine showed lower $\mathrm{IC}_{50}$ than $5.5 \mu \mathrm{M}$ on the Huh7 cell line. Compound 1e, which has an electron-withdrawing atom (4-bromo), and $\mathbf{3 h}$, which bears an electron-donating group (4-methoxy), both attached to the phenyl ring, also represented very good cytotoxicity, as two exceptions to the classification above. In the ibuprofen series $(\mathbf{1 a}-\mathbf{j}), \mathbf{1 j}\left(\mathrm{IC}_{50}\right.$ of $3.6 \mu \mathrm{M}$ for Huh7, $1.1 \mu \mathrm{M}$ for MCF7, $3.0 \mu \mathrm{M}$ for HCT116) was found to be the most active compound, followed by $1 \mathrm{e}$ ( $\mathrm{IC}_{50}$ of $4.9 \mu \mathrm{M}$ for Huh7, $9.4 \mu \mathrm{M}$ for MCF7, 7.1 $\mu \mathrm{M}$ for HCT116), $\mathbf{1 g}\left(\mathrm{IC}_{50}\right.$ of $5.0 \mu \mathrm{M}$ for Huh7, $6.3 \mu \mathrm{M}$ for MCF7, $4.0 \mu \mathrm{M}$ for HCT116) and $\mathbf{1 h}\left(\mathrm{IC}_{50}\right.$ of $5.3 \mu \mathrm{M}$ for Huh7, 5.2 $\mu \mathrm{M}$ for MCF7, $4.2 \mu \mathrm{M}$ for HCT116). In the flurbiprofen series $(\mathbf{3 a}-\mathbf{j})$, 3d $\left(\right.$ IC $_{50}$ of $3.7 \mu \mathrm{M}$ for Huh7, $7.6 \mu \mathrm{M}$ for MCF7, $6.9 \mu \mathrm{M}$ for HCT116) showed the best cytotoxicity, followed by $3 \mathrm{c}$ (IC $\mathrm{IC}_{50}$ of $3.9 \mu \mathrm{M}$ for Huh7, 8.7 $\mu \mathrm{M}$ for MCF7, $7.8 \mu \mathrm{M}$ for HCT116), 3f (IC 50 of $4.3 \mu \mathrm{M}$ for Huh7, $7.8 \mu \mathrm{M}$ for MCF7, $7.1 \mu \mathrm{M}$ for HCT116), 3h (IC 50 of $4.3 \mu \mathrm{M}$ for Huh7, $2.6 \mu \mathrm{M}$ for MCF7, $4.4 \mu \mathrm{M}$ for HCT116), 3b (IC I0 $_{\text {of }} 4.9 \mu \mathrm{M}$ for Huh7, $8.1 \mu \mathrm{M}$ for MCF7, $10.5 \mu \mathrm{M}$ for HCT116) and $3 e$ (IC 50 of $5.0 \mu \mathrm{M}$ for Huh7, $7.4 \mu \mathrm{M}$ for MCF7, 7.1 $\mu \mathrm{M}$ for HCT116) against the Huh7 cell line (Table 1 ). 
Table 1

$\mathrm{IC}_{50}(\mu \mathrm{M})$ values of the compounds as a result of the SRB assay

\begin{tabular}{|c|c|c|c|c|c|c|c|}
\hline Compds & Huh7 & MCF7 & HCT116 & Compds & Huh7 & MCF7 & HCT116 \\
\hline Ibu & $37.2^{\mathrm{a}} \pm 16$ & $\mathrm{NI}$ & $\mathrm{NI}$ & $2 c$ & $5.6 \pm 1.4$ & $10.1 \pm 1.6$ & $8.8 \pm 1.2$ \\
\hline Nap & $\mathrm{NI}^{\mathrm{b}}$ & $\mathrm{NI}$ & $\mathrm{NI}$ & 2d & $10.7 \pm 2.5$ & $14.6 \pm 2.1$ & $14.0 \pm 0.3$ \\
\hline Flu & $\mathrm{NI}$ & $\mathrm{NI}$ & $\mathrm{NI}$ & $2 e$ & $9.3 \pm 6.3$ & $11.5 \pm 0.8$ & $11.7 \pm 2.5$ \\
\hline 1 & $67.9 \pm 5.7$ & $16.1 \pm 6.6$ & $27.4 \pm 6.6$ & 2f & $14.7 \pm 4.5$ & $18.8 \pm 2.4$ & $15.1 \pm 1.9$ \\
\hline 2 & $40.8 \pm 1.2$ & $22.3 \pm 8.0$ & $20.2 \pm 10$ & $2 g$ & $8.2 \pm 1.9$ & $11.0 \pm 1.3$ & $10.2 \pm 0.9$ \\
\hline 3 & $\mathrm{NI}$ & $\mathrm{NI}$ & $\mathrm{NI}$ & $2 h$ & $8.5 \pm 0.1$ & $6.6 \pm 0.1$ & $6.5 \pm 3.5$ \\
\hline $1 a$ & $6.1 \pm 1.2$ & $9.7 \pm 3.0$ & $7.6 \pm 0.2$ & $2 \mathbf{i}$ & $14.8 \pm 1.5$ & $6.9 \pm 0.1$ & $10.8 \pm 3.1$ \\
\hline 1b & $7.8 \pm 2.2$ & $8.9 \pm 0.8$ & $12.4 \pm 0.5$ & $2 \mathbf{j}$ & $16.0 \pm 7.0$ & $8.8 \pm 0.8$ & $11.7 \pm 3.0$ \\
\hline 1c & $5.7 \pm 2.5$ & $8.8 \pm 1.1$ & $6.7 \pm 1.2$ & $3 a$ & $6.7 \pm 2.3$ & $7.4 \pm 1.3$ & $9.7 \pm 1.6$ \\
\hline 1d & $7.5 \pm 4.0$ & $11.8 \pm 3.0$ & $11.1 \pm 4.7$ & $3 b$ & $4.9 \pm 2.8$ & $8.1 \pm 3.5$ & $10.5 \pm 2.2$ \\
\hline 1e & $4.9 \pm 1.4$ & $9.4 \pm 0.6$ & $7.1 \pm 0.2$ & $3 c$ & $3.9 \pm 1.0$ & $8.7 \pm 0.5$ & $7.8 \pm 0.3$ \\
\hline 1f & $\mathrm{NI}$ & $\mathrm{NI}$ & $\mathrm{NI}$ & $3 d$ & $3.7 \pm 0.3$ & $7.6 \pm 0.5$ & $6.9 \pm 0.7$ \\
\hline $1 \mathrm{~g}$ & $5.0 \pm 0.2$ & $6.3 \pm 0.7$ & $4.0 \pm 0.6$ & $3 e$ & $5.0 \pm 2.5$ & $7.4 \pm 1.7$ & $7.1 \pm 4.4$ \\
\hline $1 \mathrm{~h}$ & $5.3 \pm 4.0$ & $5.2 \pm 1.6$ & $4.2 \pm 4.0$ & $3 f$ & $4.3 \pm 3.0$ & $7.8 \pm 2.7$ & $7.1 \pm 0.8$ \\
\hline 1i & $8.4 \pm 1.8$ & $4.2 \pm 0.9$ & $6.5 \pm 0.2$ & $3 g$ & $7.2 \pm 0.3$ & $5.0 \pm 1.1$ & $4.8 \pm 0.2$ \\
\hline $\mathbf{1 j}$ & $3.6 \pm 1.8$ & $1.1 \pm 0.8$ & $3.0 \pm 2.9$ & $3 h$ & $4.3 \pm 1.5$ & $2.6 \pm 1.7$ & $4.4 \pm 0.9$ \\
\hline $\mathbf{2 a}$ & $5.7 \pm 2.9$ & $11.7 \pm 3.0$ & $8.9 \pm 0.8$ & $3 \mathbf{i}$ & $9.4 \pm 1.6$ & $4.3 \pm 4.3$ & $6.1 \pm 0.02$ \\
\hline $2 b$ & $7.0 \pm 3.8$ & $15.8 \pm 3.8$ & $13.1 \pm 0.5$ & $\mathbf{3 j}$ & $8.4 \pm 0.9$ & $4.8 \pm 0.6$ & $5.4 \pm 1.1$ \\
\hline
\end{tabular}

a Represents $\mathrm{IC}_{50}$ values.

b NI stands for 'No Inhibition'. ' \pm ' represents standard deviations, $R^{2} \geqslant 0.8$. IC 50 for positive control (CPT) was $\leqslant 0.1 \mu \mathrm{M}$.

The compounds with significant cytotoxic activities $(\mathbf{1 e}, \mathbf{1 g}, \mathbf{1 h}$, $\mathbf{1 j}, \mathbf{3 b}, \mathbf{3 c}, \mathbf{3 d}, \mathbf{3 e}, \mathbf{3 f}, \mathbf{3 h}$ ), the aminomercaptotriazoles (1-3) and the NSAIDs were selected for further evaluation. The bioactivities of these compounds were analyzed on a panel of HCC cell lines: HepG2, Hep-3B, Mahlavu, FOCUS and Snu475. Similar to initial screening results, the NSAIDs and compounds 1-3 displayed low or no cytotoxic activity. All selected condensed derivatives displayed significant cytotoxic activities (Table 2).

\subsubsection{Real time cell growth analysis with selected compounds}

For dynamic and quantitative measurements of the cytotoxic effects of the compounds $1 \mathrm{e}, \mathbf{1 g}, \mathbf{1 h}, \mathbf{1 j}, \mathbf{3 b}, \mathbf{3 c}, \mathbf{3 d}, \mathbf{3 e}, \mathbf{3 f}$ and $\mathbf{3 h}$, a label-free, real-time cell electronic sensing (RT-CES) assay was performed with Huh7 cells. Cells were treated with the compounds according to their $\mathrm{IC}_{100}$, IC $\mathrm{I}_{50}$ and $\mathrm{IC}_{25}$ concentrations and cell impedance was monitored during $72 \mathrm{~h}$. The graphs represent timedependent effects of the seleceted compounds on cell growth (Fig. 1). The results were normalized to DMSO-treated control cells.

In general, apoptosis is a cellular process usually triggered after the fourth hours of anticancer drug treatment and may take up to $24 \mathrm{~h}$ in cancer cell lines. The time-dependent growth inhibition graphs demonstrated cytotoxicities in parallel to $\mathrm{IC}_{100}, \mathrm{IC}_{50}$ and $\mathrm{IC}_{25}$ values obtained from initial cytotoxicity analysis (Tables 1 and 2). The course of cell growth inhibition predicts the type of cell death as apoptosis which was further analyzed below.

\subsubsection{Characterization of cell death as apoptosis}

Cells were treated with $10 \mu \mathrm{M}$ of the compounds and compared to DMSO control. After $48 \mathrm{~h}$, the Hoechst-dye-stained cells' nuclei were observed under a fluorescence microscope. As seen in Figure 2, the cell morphologies of the compound-treated cells were distinctive from the DMSO-treated cells; condensed bright nuclei and a 'horseshoe' structure indicated apoptotic cells in treated samples (except 3e and 3f). Furthermore, apoptosis was confirmed with $1 \mathrm{~g}$ and $\mathbf{1 h}$ by the presence of cleaved-PARP protein below.

\subsubsection{Cell cycle analysis of compound-treated cells}

To further elucidate the apoptotic cell death, we checked the effects of the compounds $1 \mathbf{e}, \mathbf{1 g}, \mathbf{1 h}, \mathbf{1 j}, \mathbf{3 b}, \mathbf{3 c}, \mathbf{3 d}, \mathbf{3 e}, \mathbf{3 f}$ and $\mathbf{3 h}$ with cell-cycle analysis in Huh7 cells. Cells were treated with $10 \mu \mathrm{M}$ of the compounds or DMSO controls for 24-hour and 48hour periods and the comparative cell fate was measured.

Analysis of histograms showed that there was an apparent increase in $S_{u b G}$ cell population in the presence of $\mathbf{1 e}, \mathbf{1 g}, \mathbf{1 h}$, 3c and $\mathbf{3 h}$ indicating apoptotic cell death (Fig. 3).

Table 2

$\mathrm{IC}_{50}(\mu \mathrm{M})$ values of the compounds as a result of the SRB assay on the liver carcinoma cell line panel

\begin{tabular}{|c|c|c|c|c|c|c|}
\hline Compds & Huh7 & HepG2 & Нер-3В & Mahlavu & FOCUS & Snu475 \\
\hline Ibu & $37.2^{\mathrm{a}} \pm 16$ & $\mathrm{NI}$ & $\mathrm{NI}$ & $\mathrm{NI}$ & $\mathrm{NI}$ & $\mathrm{NI}$ \\
\hline Nap & $\mathrm{NI}^{\mathrm{b}}$ & $\mathrm{NI}$ & NI & $\mathrm{NI}$ & $\mathrm{NI}$ & $\mathrm{NI}$ \\
\hline Flu & $\mathrm{NI}$ & $\mathrm{NI}$ & NI & NI & NI & $\mathrm{NI}$ \\
\hline 1 & $23.0 \pm 2.3$ & NI & $13.1 \pm 2.3$ & $16.2 \pm 1.9$ & $\mathrm{NI}$ & $11.7 \pm 3.5$ \\
\hline 2 & NI & $40.0 \pm 0.2$ & $1.9 \pm 3.3$ & NI & NI & $15.9 \pm 3.3$ \\
\hline 3 & $43.1 \pm 3.7$ & $21.4 \pm 3.2$ & NI & NI & $\mathrm{NI}$ & NI \\
\hline $1 e$ & $9.4 \pm 1.9$ & $6.4 \pm 2.3$ & $8.3 \pm 0.9$ & $8.9 \pm 1.3$ & $5.9 \pm 0.8$ & $10.1 \pm 2.3$ \\
\hline $1 \mathrm{~g}$ & $6.2 \pm 0.1$ & $7.3 \pm 1.3$ & $5.3 \pm 0.9$ & $8.5 \pm 0.7$ & $6.8 \pm 1.3$ & $8.7 \pm 0.3$ \\
\hline $1 \mathrm{~h}$ & $3.7 \pm 1.3$ & $3.8 \pm 0.6$ & $6.5 \pm 0.6$ & $13.6 \pm 5$ & $2.4 \pm 1.3$ & $8.5 \pm 0.8$ \\
\hline $\mathbf{1 j}$ & $9.5 \pm 0.5$ & $9.7 \pm 0.9$ & $6.4 \pm 0.04$ & $9.1 \pm 0.8$ & $8.8 \pm 0.6$ & $6.8 \pm 2.4$ \\
\hline $3 \mathbf{b}$ & $6.3 \pm 0.7$ & $5.1 \pm 3.0$ & $2.6 \pm 1.1$ & $7.4 \pm 0.7$ & $3.5 \pm 1.1$ & $6.6 \pm 2.7$ \\
\hline $3 c$ & $6.4 \pm 1.9$ & $6.7 \pm 2.2$ & $3.8 \pm 0.2$ & $6.1 \pm 1.4$ & $5.0 \pm 2.9$ & $3.8 \pm 2.2$ \\
\hline $3 d$ & $7.3 \pm 0.8$ & $8.6 \pm 1.5$ & $4.2 \pm 1.2$ & $6.6 \pm 1.3$ & $5.4 \pm 2.9$ & $4.7 \pm 1.3$ \\
\hline $3 e$ & $8.7 \pm 1.9$ & $3.7 \pm 0.6$ & $1.5 \pm 1.0$ & $6.2 \pm 2.5$ & $8.5 \pm 2.9$ & $7.0 \pm 1.9$ \\
\hline $3 f$ & $7.1 \pm 2.2$ & $4.3 \pm 4.1$ & $2.9 \pm 2.7$ & $9.4 \pm 3.8$ & $3.5 \pm 1.0$ & $7.1 \pm 1.9$ \\
\hline $3 h$ & $4.5 \pm 1.9$ & $4.2 \pm 1.6$ & $3.5 \pm 1.1$ & $5.8 \pm 0.9$ & $4.4 \pm 2.3$ & $6.7 \pm 0.4$ \\
\hline $\mathrm{CPT}$ & 0.1 & $<1$ & $<1$ & $<1$ & $<1$ & $<1$ \\
\hline
\end{tabular}

a Represents $\mathrm{IC}_{50}$ values.

b NI stands for 'No Inhibition'. ' \pm ' represents standard deviations $R^{2} \geqslant 0.8$. 

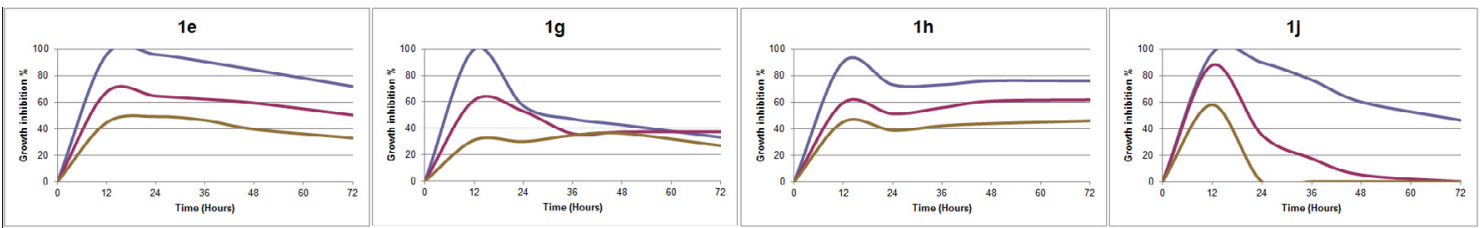

$3 \mathrm{~b}$

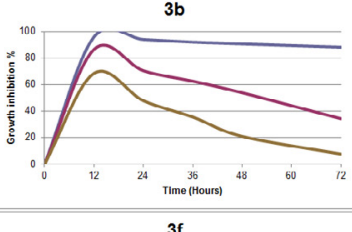

$3 \mathrm{c}$
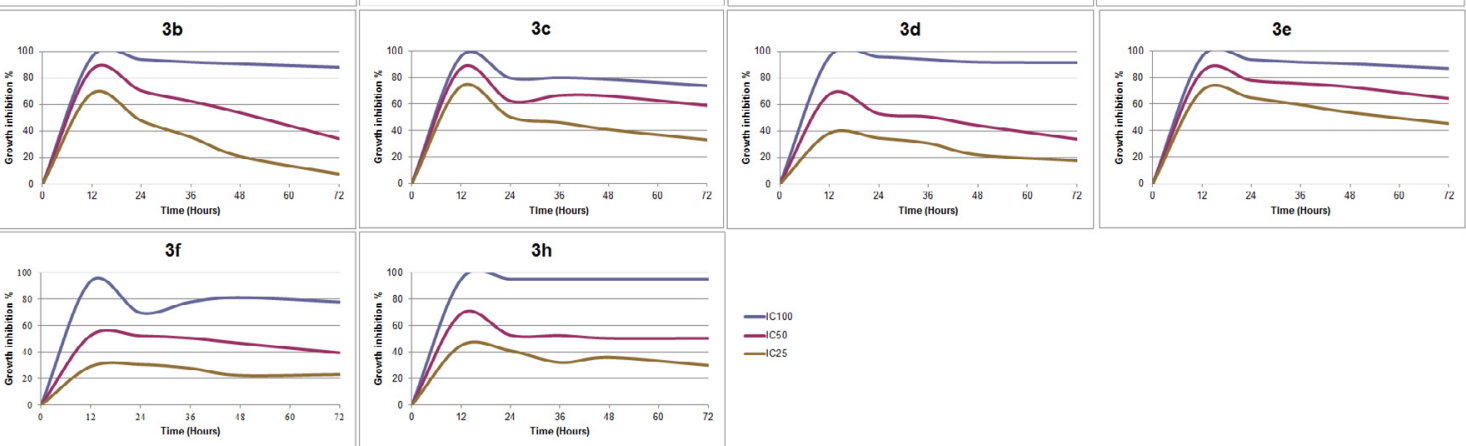

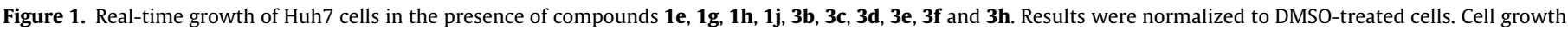
index was acquired every $30 \mathrm{~min}$.

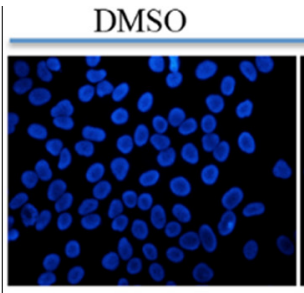

le

$\lg$

$1 \mathrm{~h}$
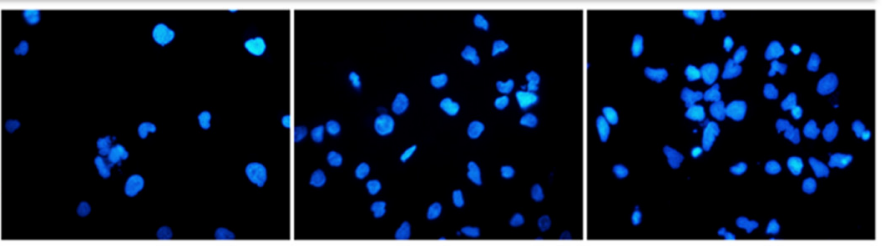

$1 \mathrm{j}$

$3 \mathrm{~b}$

$3 \mathrm{c}$

$3 d$
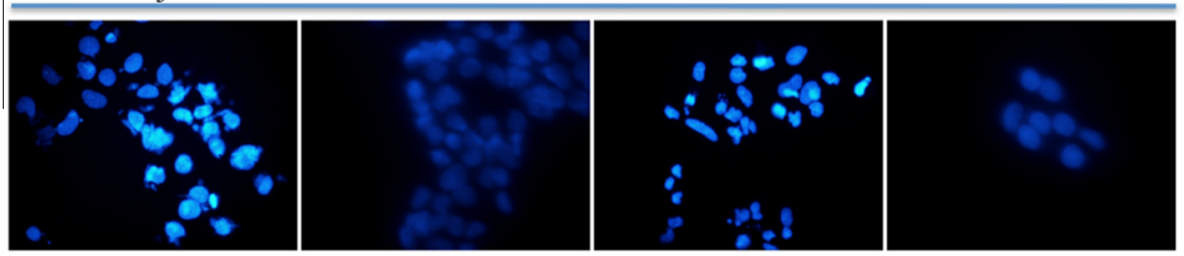

$3 \mathrm{e}$

$3 f$

$3 \mathrm{~h}$
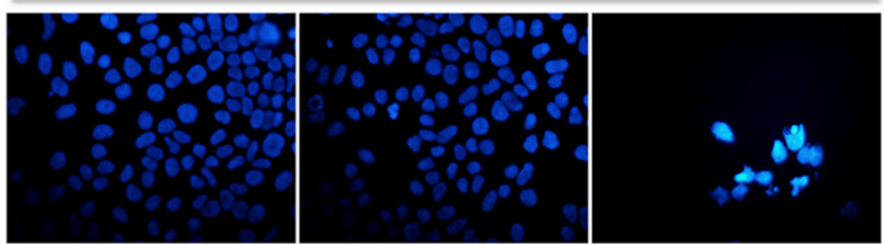

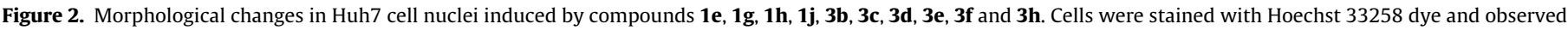
under a fluorescence microscope. Control group was DMSO. Images were taken with 40x objectives.

We have selected the compounds carrying ibuprofen residue at the third position of the thiadiazine ring 1g (3-[1-[4-(2-methylpropyl)phenyl]ethyl]-6-(4-methylphenyl)-7H-1,2,4-triazolo[3,4b]-1,3,4-thiadiazine) and $\mathbf{1 h}$ (3-[1-[4-(2-methylpropyl)phenyl] ethyl]-6-(4-methoxyphenyl)-7H-1,2,4-triazolo[3,4-b]-1,3,4-thiadiazine) for further mechanistic analysis leading to apoptotic cell death with two different liver cancer cells (Huh7 and Mahlavu).

\subsubsection{Compounds $1 \mathrm{~g}$ and $1 \mathrm{~h}$ induced oxidative stress in liver cancer cells}

NSAIDs were shown to induce oxidative stress, which may be a mechanism for the anticancer activity of our compounds. ${ }^{40}$ Therefore, we investigated the induction of oxidative stress with novel tri- azolothiadiazine derivatives $\mathbf{1 g}$ and $\mathbf{1 h}$ in human liver cancer cell lines, Huh7 and Mahlavu (MV). Cells were treated with $10 \mu \mathrm{M}$ of compounds for $48 \mathrm{~h}$ and then analyzed with flow cytometry. Both $\mathbf{1 g}$ and $\mathbf{1 h}$ treatment resulted in accumulation of reactive oxygen species (ROS) positive cells when compared to DMSO controls (Fig. 4A). In this assay, cells grown in selenium deficient serum free medium were used as positive controls of ROS accumulation. ${ }^{41}$

Moreover, in order to confirm the induction of oxidative stress, we analyzed in situ ROS accumulation with dichloro-dihydro fluorescein diacetate (DCFH-DA) under fluorescent microscope. This assay also verified in situ the accumulation of ROS positive cells leading to oxidative stress induction in the presence of both compounds $\mathbf{1 g}$ and $\mathbf{1 h}$ (Fig. 4B). 

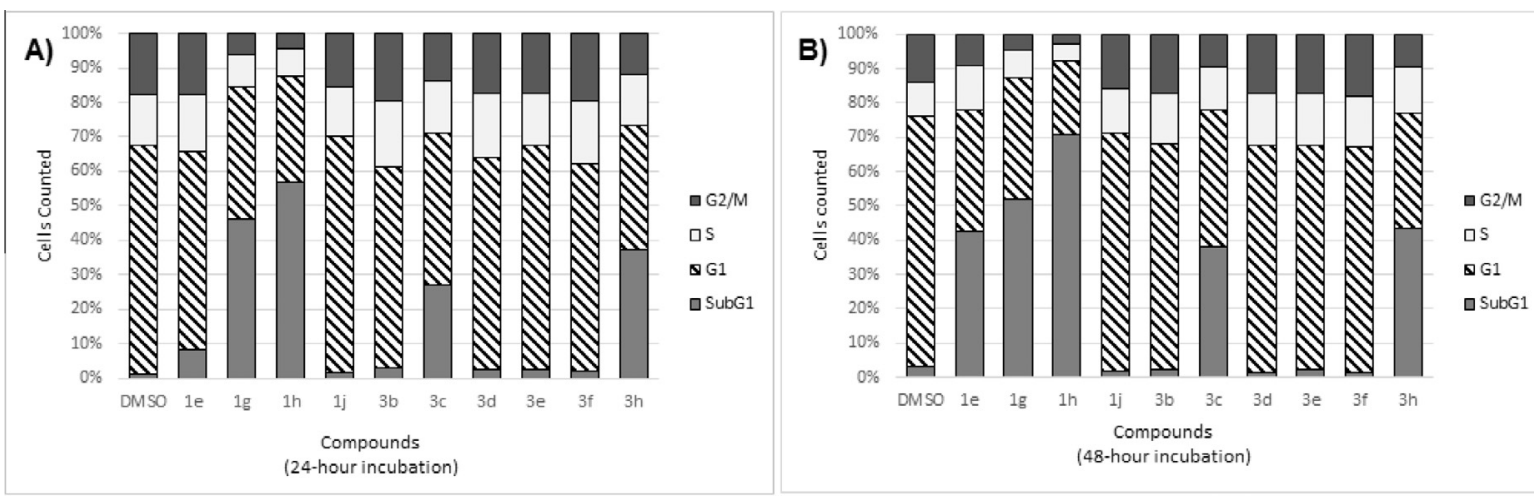

Figure 3. Cell cycle analysis of Huh7 cells treated with compounds or DMSO controls after (A) 24-hour and (B) 48-hour of incubation.
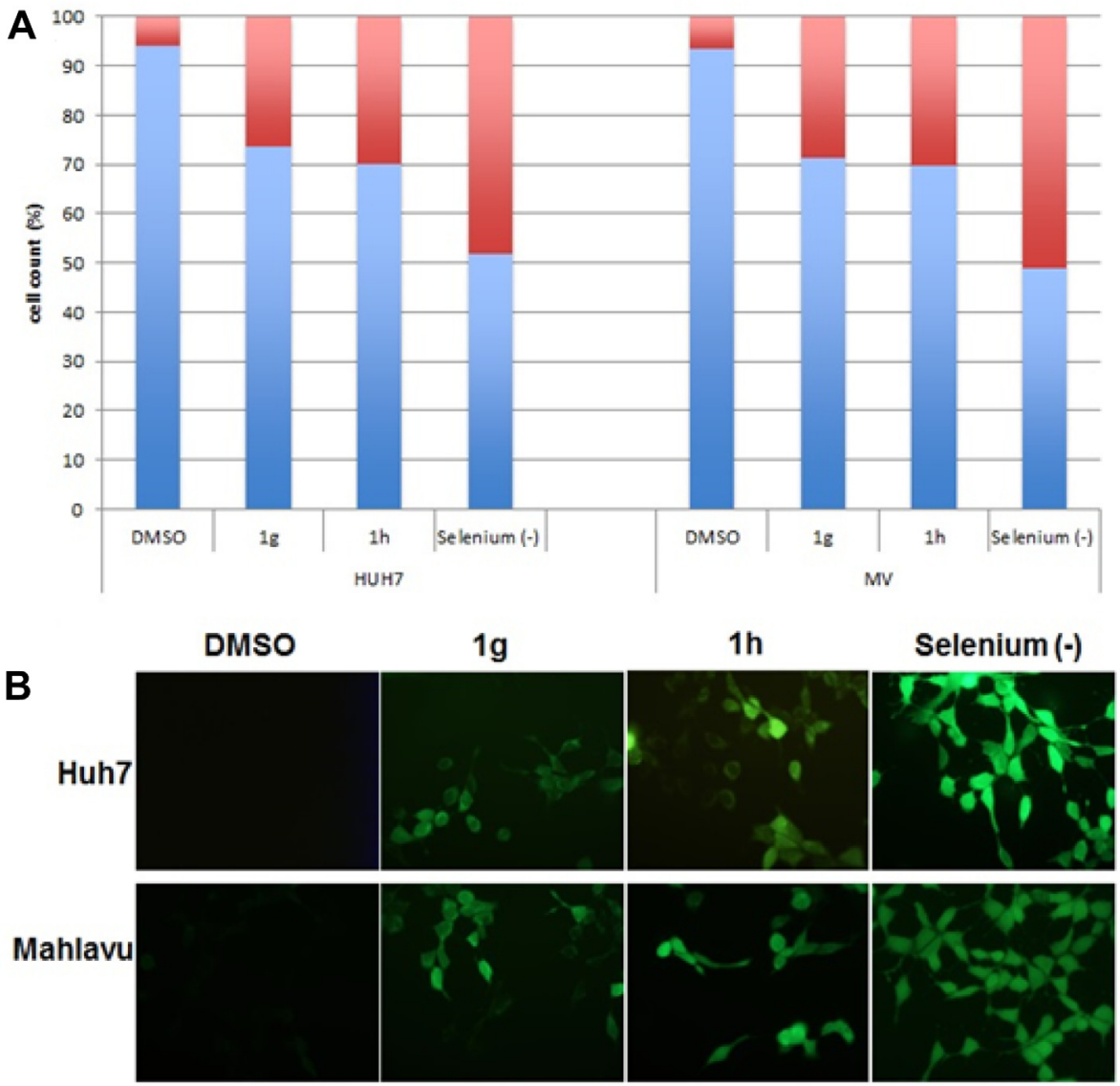

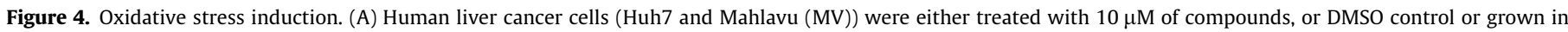

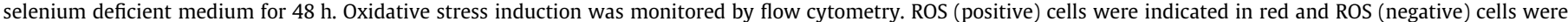

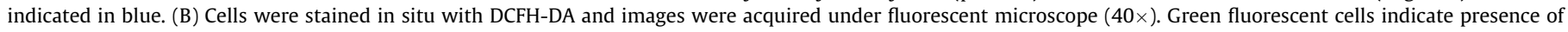
ROS.

\subsubsection{Apoptosis due to $1 \mathrm{~g}$ and $1 \mathrm{~h}$ involves phosphorylation of $\beta$-catenin}

Previous findings demonstrated that ibuprofen might exhibit its chemopreventive activity through $\beta$-catenin oncogene inhibition. ${ }^{3}$ Therefore, we investigated the levels of both phosphorylated and un-phosphorylated forms of $\beta$-catenin in liver cancer cells treated with $\mathbf{1 g}$ and $\mathbf{1 h}$. The compounds led to an increase in $\beta$-catenin phosphorylation, which targets this protein for degradation, while no change was observed in un-phosphorylated $\beta$-catenin levels (Fig. 5A). It was shown that the upstream regulators of $\beta$-catenin are Akt and GSK3 $\beta$ proteins. ${ }^{42}$ Thus, we also checked status of these proteins in the presence of the compounds. $\mathbf{1 g}$ and $\mathbf{1 h}$ caused significant decrease in phosphorylated active form of Akt (p-Akt) and phosphorylated inactive form of GSK3 $\beta$ (p-GSK3 $\beta$ ) (Fig. 5A). While Akt pathway is hyperactive in Mahlavu cells due to PTEN deletion, in Huh7 cells, the pathway is not hyperactive. For this reason, p-Akt bands were observed only in Mahlavu but not in Huh7 cells (Fig. 5A). Moreover, it was suggested that $\beta$-catenin transcriptionally activates cyclin D1, which is an important factor of cellular replication machinery. ${ }^{42}$ In liver cancer cells treated with 
compounds $\mathbf{1 g}$ and $\mathbf{1 h}$, levels of cyclin D1 significantly decreased due to $\beta$-catenin phosphorylation, when compared to the DMSO controls (Fig. 5A).

Since we have shown that compounds $\mathbf{1 g}$ and $\mathbf{1 h}$ induced oxidative stress, we also investigated ASK-1 and JNK proteins that are reported to be involved in this process. Our data showed that $\mathbf{1 g}$ and $\mathbf{1 h}$ decreased the levels of ASK-1 phosphorylation at Ser83 or Ser966, which are the residues phosphorylated due to oxidative stress. Phosphorylation at Ser83 and Ser966 leads to inhibition of this protein. Thus, decrease in these forms of the protein indicates the activation of ASK-1 by $\mathbf{1 g}$ and $\mathbf{1 h}$ in treated liver cancer cells (Fig. 5B). Due to the activation of ASK-1, downstream target SAPK/JNK protein was shown to be phosphorylated in the presence of $\mathbf{1 g}$ and $\mathbf{1 h}$ (Fig. 5B). Finally, induction of oxidative stress by $\mathbf{1 g}$ and $\mathbf{1 h}$ leads to apoptotic cell death as demonstrated by the presence of cleaved PARP protein (Fig. 5B) in addition to cell cycle analysis (Fig. 3).

Together our results demonstrated that compounds $\mathbf{1 g}$ and $\mathbf{1 h}$ cause ROS accumulation, which in turn results in the inhibition of Akt cell survival protein, and the activation of ASK-1 protein.

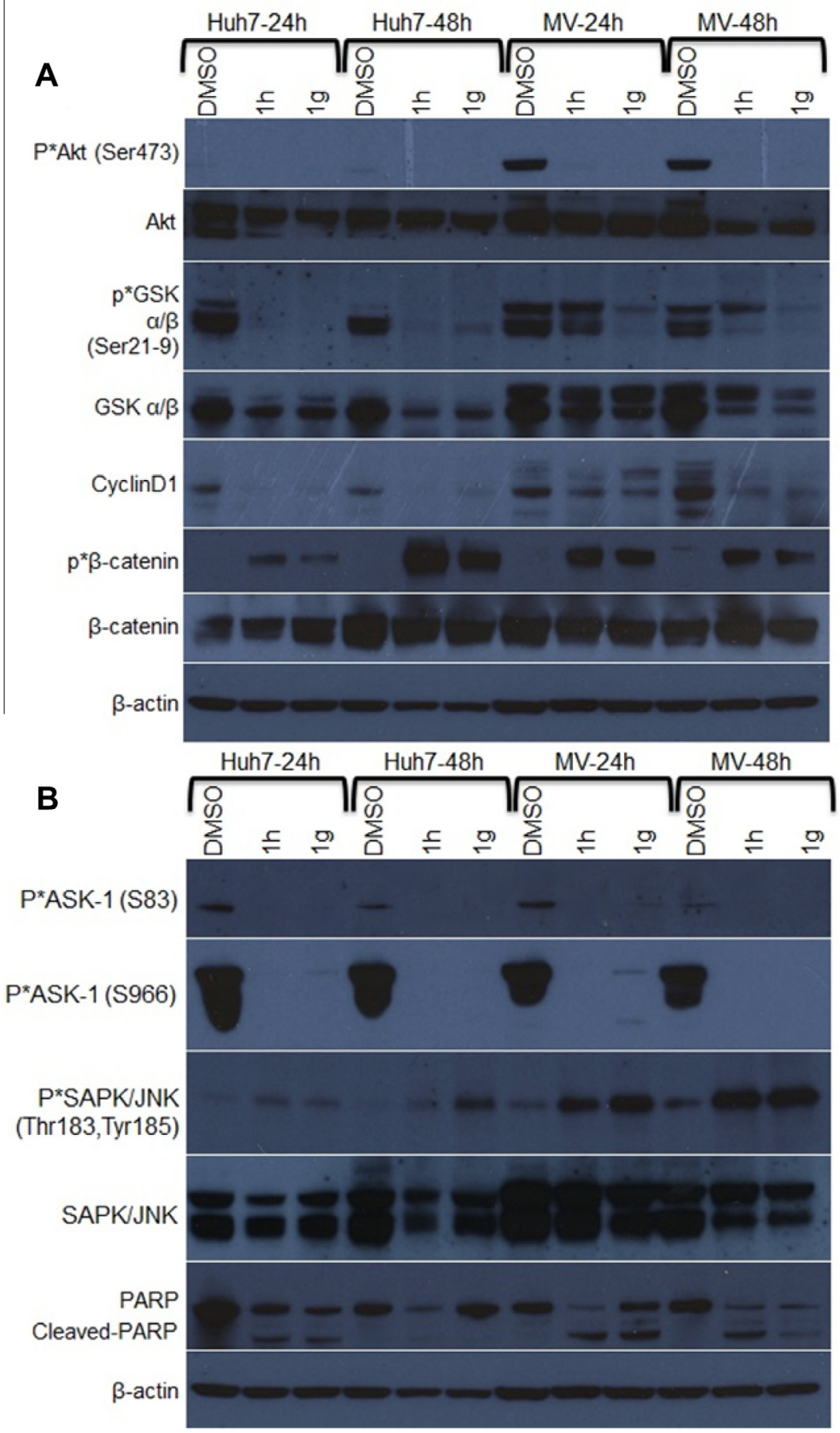

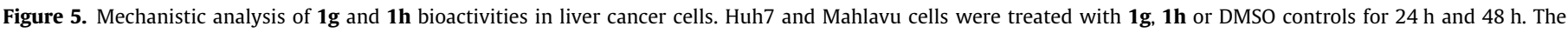

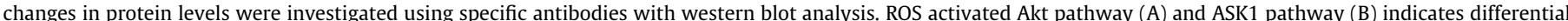

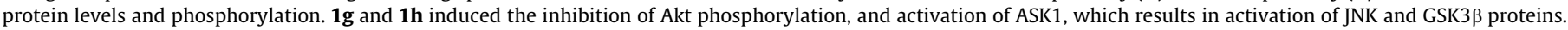
Then the decrease in $\mathrm{p}^{*} \beta$-catenin and cyclin D1 results in apoptotic cell death induction shown by PARP cleavage. $\beta$-actin was used for equal protein loading. 


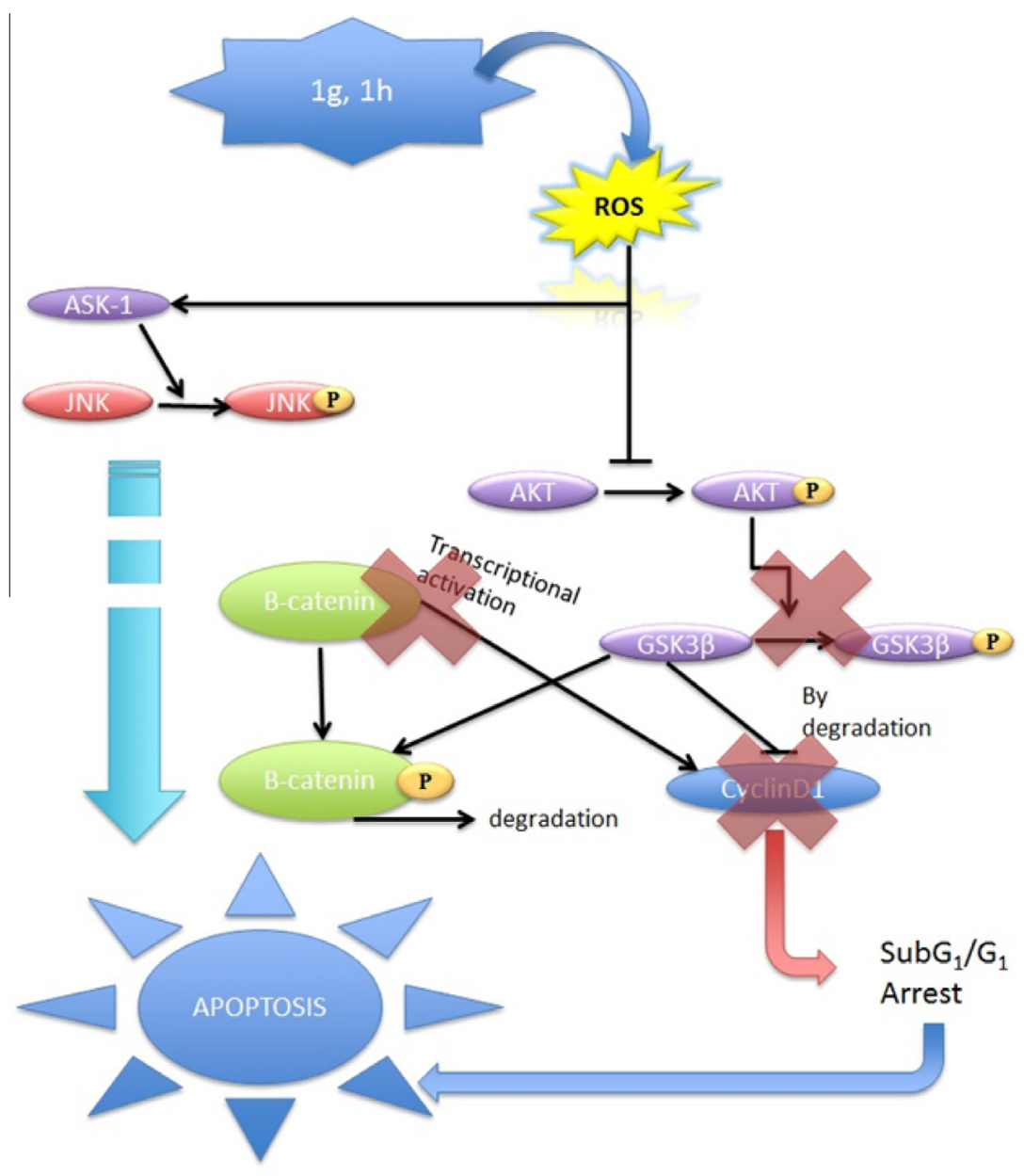

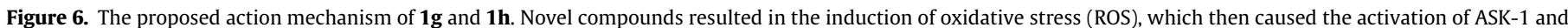

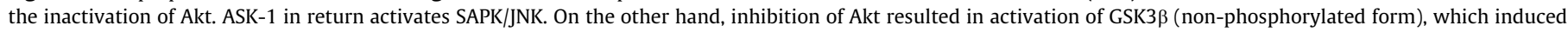

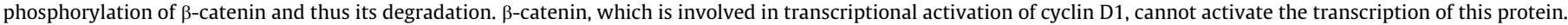
In addition, active GSK3 $\beta$ induces the cyclin D1 degradation. Finally, $\mathbf{1 g}$ and $\mathbf{1 h}$ induces $\mathrm{SubG}_{1} / \mathrm{G}_{1}$ arrest and apoptotic cell death in liver cancer cells.

ASK-1 then activates JNK protein and induction of apoptosis. On the other hand, inhibition of Akt results in the activation of GSK3 $\beta$. Active GSK3 $\beta$ induces phosphorylation of $\beta$-catenin therefore its degradation. Treatment with $\mathbf{1 g}$ and $\mathbf{1 h}$ significantly altered cyclin D1 levels by the inhibition of its transcriptional activator $\beta$-catenin and activation of its degradation by GSK3 $\beta$. Decrease in cyclin D1 protein levels leads to $\mathrm{SubG}_{1}$ arrest and induction of apoptosis in liver cancer cells treated with $\mathbf{1 g}$ and $\mathbf{1 h}$ compounds (Fig. 6).

\subsection{In silico analysis}

\subsubsection{QSAR}

It is known that SAR discontinuity (where small changes in chemical structure lead to large changes in activity, also known as 'activity cliffs') presents a challenge to successful QSAR modeling. ${ }^{43}$ At first glance, it would appear that the lack of inhibition exhibited by $\mathbf{1 f}$ represents an activity cliff since all other compounds based on scaffold $\mathbf{1}$, and $\mathbf{2 f}$ and $\mathbf{3 f}$, show good activity. However, the lack of activity of $\mathbf{1 f}$ does not fit the definition of an activity cliff; it is useful to consider activity cliffs only if one cliff partner has a potency in the nanomolar range. ${ }^{44}$ Since none of the inhibitors in this dataset exhibit such potency, the real difference in activity between $\mathbf{1 f}$ and the other compounds is insufficient for this to be a barrier to QSAR modeling.
A QSAR model was built using QSARINS with the average $\mathrm{IC}_{50}$ values of the compounds against the three cancer cells lines used as the activity response variable (Table 1 ). The model was evolved via Genetic Algorithm in multiple iterations until a maximum of three descriptors was reached; the predictive performance achieved at this level of complexity was sufficient so the number of variables was not increased to prevent over-fitting and produce a maximally simple model suitable for future use.

The $R^{2}$ of the best model that passed the maximum number of external validation tests (4 out of 5) was 0.70 (with an adjusted $R^{2}$ of 0.64 ; unlike $R^{2}$, the adjusted $R^{2}$ increases when a new explanator is included only if the new explanator improves the $R^{2}$ more than would be expected by chance ${ }^{45}$ ), showing good correlation with experimental $\mathrm{IC}_{50}$ (Fig. 7). Details of the three descriptors used for this model, the model equation, and the inter-descriptor correlations are listed in Table 3.

None of the descriptors can be considered highly collinear with another, meaning that each is contributing substantially to the prediction. ${ }^{50,51}$ None of the compounds included in the final model building had errors in prediction larger than a factor of 10 (Fig. 7), suggesting an applicability domain sufficiently broad for the model to be useful, and that all structural outliers had been correctly identified and removed. The final QSAR model resulting from this work therefore appears robust. 


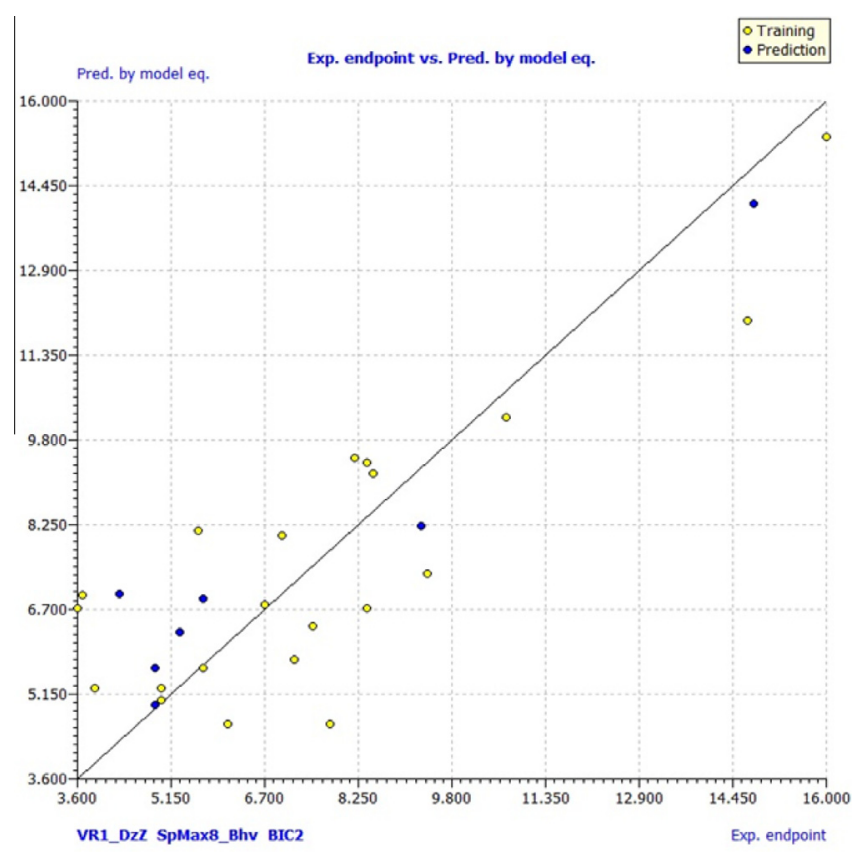

Figure 7. Experimental activities versus activities predicted by the model.

Table 3

Details of the best QSAR model selected by Genetic Algorithm

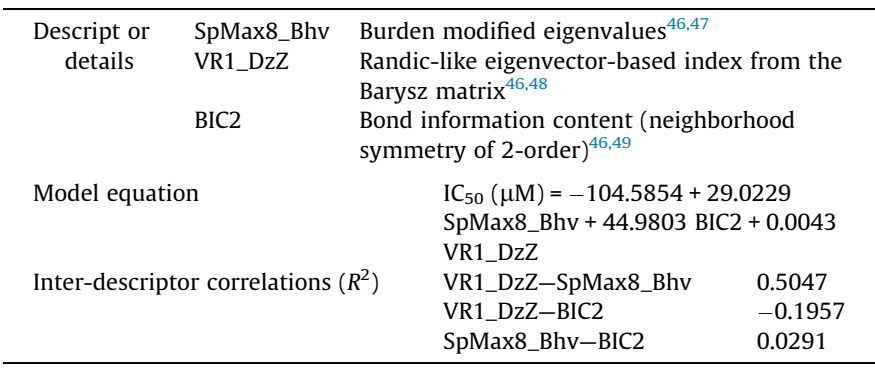

\subsubsection{Molecular docking}

The origins of the lack of inhibitory activity of compound $\mathbf{1 f}$ were investigated by molecular docking. Models of Ibu and Flu present in crystal structures $1 \mathrm{EQG}$ and $1 \mathrm{EQH}$ respectively were re-docked into COX-1 using Autodock, which correctly reproduced their known binding modes, with RMSDs of 0.9 and $1.2 \AA$ (Supplementary data Figs. S69A and S69B, respectively). Nap was also docked and, although no crystal structure is available of it in complex with COX-1 or -2 , it was predicted to bind in a mode similar to that of Ibu and Flu, consistent with a shared pharmacophore (Supplementary data Fig. S69C).

Compounds 1f, $\mathbf{1 g}, \mathbf{1 h}$, and $\mathbf{1 j}$ were docked into COX-1 (PDB code $1 \mathrm{EQG}$ ). All but $\mathbf{1 f}$ could be accommodated by the binding site pocket in a pose consistent with the known binding positions of the Ibu, Flu and Nap anchor fragments. Figure 8B-D show the $\mathbf{1 g}, \mathbf{1 h}$, and $\mathbf{1 j}$ docking poses; they are positioned such that their methylpropylphenyl moieties are still encompassed by the hydrophobic basin formed by Val349, Leu352, Phe518 and Ile523. In contrast, Autodock calculated that the 1f pose with the lowest binding free energy is situated completely outside of this deep pocket, in a shallower depression on the surface of the protein (Fig. 8A).

This compromised binding mode is reflected in the predicted binding affinities, which are significantly tighter for $\mathbf{1 g}, \mathbf{1 h}$, and $\mathbf{1 j}$ than for 1f. It is interesting that a relatively minor change in functional group exhibits such a marked influence on binding; the nitro group present in $\mathbf{1 f}$ is differentiated from all of the other $\mathrm{R}^{\prime}$ groups in that it carries a substantial anisotropic charge distribution. Manual alchemical transformation of the docked poses of $\mathbf{1 g}$, $\mathbf{1 h}$, and $\mathbf{1 j}$ into $\mathbf{1 f}$ reveals that the negatively charged oxygen atoms of this nitro group are positioned close to Glu524. Thus, charge repulsion may be the origin of the suboptimal predicted binding mode, and lack of activity, exhibited by this compound. To test this hypothesis, compounds $\mathbf{2 f}$ and $\mathbf{3 f}$, which both carry the nitro group (and yet exhibit good activity), were also docked into COX-1. By forming additional hydrophobic contacts with the deeper part of the hydrophobic basin (formed by Phe381, Leu384, Tyr 385 and Trp387), the larger aromatic moieties of these compounds pull the molecules' binding positions further into the pocket, moving the nitro group away from Glu524 and additionally allowing it to form hydrogen bonds with the side chain of Arg83 (Fig. 9). These modeling results are consistent with the primary mode of action of these compounds being through COX inhibition, which in turn is consistent with them being derivatives of known COX inhibitors.

\subsubsection{Confirmation of molecular docking by COX inhibition analysis}

Considering the docking results that may refer to COX inhibitory activities of compounds $\mathbf{1 g}$ and $\mathbf{1 h}$, they were further investigated with COX activity assay in vitro. COX enzyme activity was analyzed in the presence of Huh7 and Mahlavu liver cancer cells treated with $\mathbf{1 g}$ and $\mathbf{1 h}$, and results revealed that, both $\mathbf{1 g}$ and 1h possess COX inhibition. Ibu, Nap and Flu showed COX inhibition more than $70 \%$ whereas the inhibition was $65 \%$ in Huh7 and 55\% in Mahlavu cells treated with $\mathbf{1 h}$ and 54\% in Huh7 and 32\% in Mahlavu cells treated with $\mathbf{1 g}$. These results indicated that both $\mathbf{1 g}$ and $\mathbf{1 h}$ inhibit COX enzyme activity, in addition to their oxidative stress related anticancer activities (Fig. 10, Supplementary data Fig. S70). The results are found to be in correlation with in silico molecular docking results of the compounds. Previous studies showed that decreased phosphorylation of Akt via COX-2 inhibition caused apoptosis in HCC cells. ${ }^{52,53}$ Therefore, it could be concluded that the compounds might act on the inhibition of Akt pathway through COX proteins in addition to ASK-1 and JNK proteins.

\section{Conclusions}

In this study we synthesized 30 new triazolothiadiazine derivatives (1a-3j), starting with the traditional NSAIDs (ibuprofen, naproxen and flurbiprofen) and then examined their antiproliferative properties and mechanism of action in liver cancer cells. The majority of derivatives showed moderate to significant cytotoxicity. As a general consideration, our results confirmed that condensing an aminomercaptotriazole ring (1-3) with a thiadiazine provides better results for cytotoxic activity. The most interesting series of compounds are those having ibuprofen, [1-[4-(2-methylpropyl)phenyl]ethyl] (1a-j), and flurbiprofen, [1-(2-fluoro-4-biphenyl)ethyl] $(\mathbf{3} \mathbf{a}-\mathbf{j})$, residues at the third position of the ring. Many of the compounds also showed cytotoxic activity against epithelial cancer cells (Huh7, MCF7 and HCT116). Among them, compounds 1e, 1 g, 1h, 1j, 3b, 3c, 3d, 3e, 3f and $\mathbf{3 h}$, had lower $\mathrm{IC}_{50}$ values which were further studied in various human liver cancer cells.

According to fluorescent microscopy and flow cytometry analysis, the compounds $\mathbf{1 e}, \mathbf{1 g}, \mathbf{1 h}, \mathbf{3 c}$ and $\mathbf{3 h}$ were found to induce apoptosis and $\mathrm{SubG}_{1}$ arrest. Two of the compounds ( $\mathbf{1 g}$ and $\mathbf{1 h}$ ) were then selected for the investigation of mechanism of action at protein levels. It was reported that chemopreventive actions of NSAIDs, involves induction of ROS along with $\beta$-catenin oncogene 
A

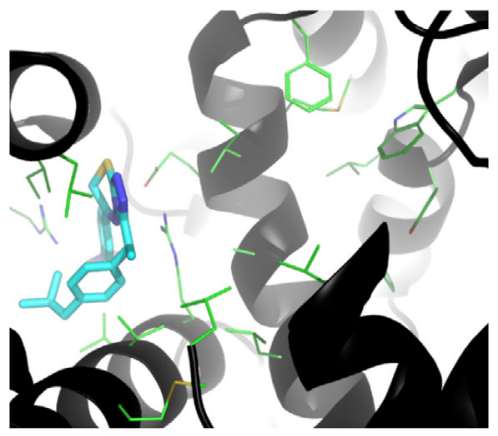

C

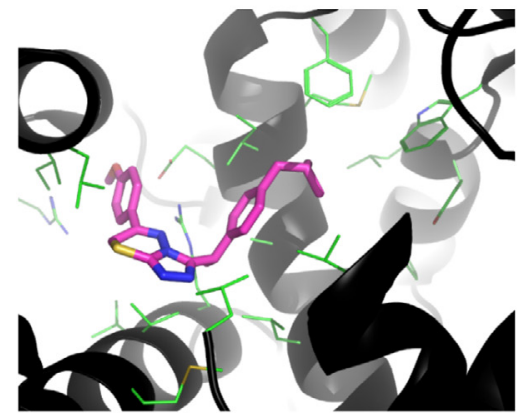

B

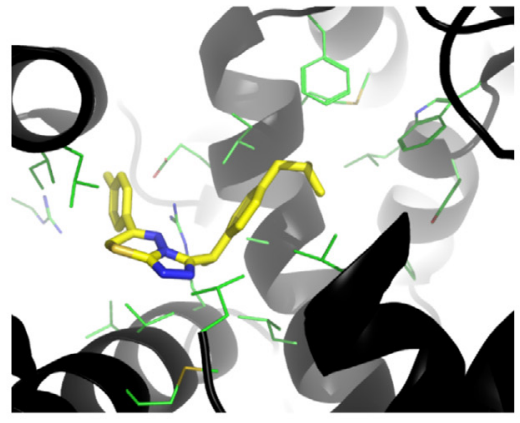

D

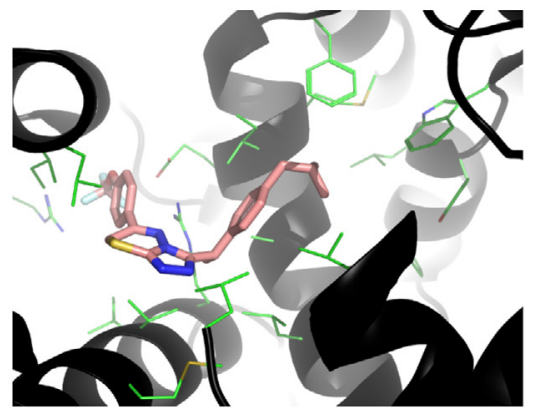

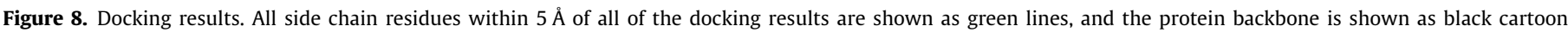
depicting secondary structure. A) $\mathbf{1 f}$ (cyan) B) $\mathbf{1 g}$ (yellow) C) $\mathbf{1 h}$ (magenta) D) $\mathbf{1 j}$ (pink).

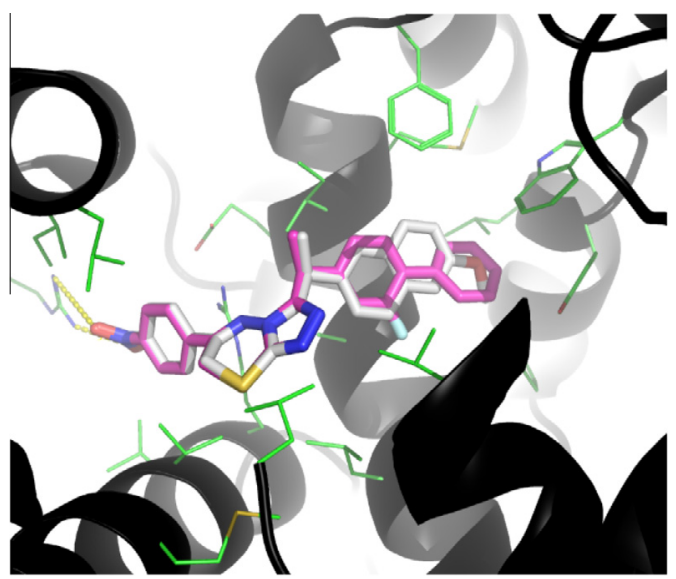

Figure 9. Docking results. All side chain residues within $5 \AA$ A of the docking results are shown as green lines, and the protein backbone is shown as black cartoon depicting secondary structure. Hydrogen bonds between their nitro groups and Arg83 are depicted as yellow dashed lines. 2 f (white) and $\mathbf{3 f}$ (magenta) dock with high predicted affinity.

inactivation. ${ }^{3,41}$ Hence, we also demonstrated the accumulation of ROS and the activation of ROS dependent apoptosis signal regulating kinase-1 (ASK-1) and inhibition of Akt protein in the presence of $\mathbf{1 g}$ and $\mathbf{1 h}$ (Figs. 5 and 6 ). As a result of ASK-1 activation, and Akt inhibition, a number of downstream proteins including $\beta$-catenin were altered resulting in cyclin D1 inactivation and ultimately leading to $\mathrm{SubG}_{1}$ arrest and apoptosis (Figs. 5 and 6). In the in silico docking analysis, we observed possible interactions of $\mathbf{1 g}$ and $\mathbf{1 h}$ with COX proteins, which is then, confirmed with COX activity assay. According to COX activity assay, both compounds showed COX-inhibiting activities that is comparable to the conventional NSAIDs (Fig. 10).

The statistically valid QSAR model based on a small number of theoretical molecular descriptors developed can be used to guide

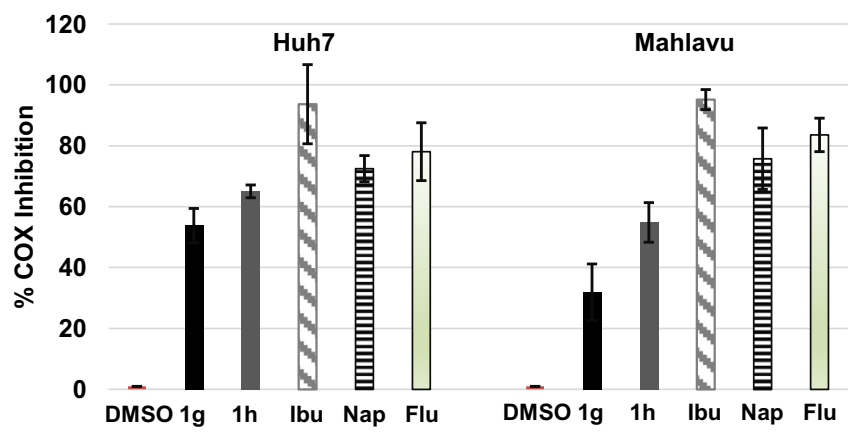

Figure 10. Effect of $\mathbf{1 g}$ and $\mathbf{1 h}$ on COX enzyme activity. Huh7 and Mahlavu (MV) liver cancer cells were treated with $10 \mu \mathrm{M}$ of novel compounds or NSAIDs (Ibu, Nap, Flu) or DMSO controls for $48 \mathrm{~h}$. Then COX enzyme activity was assayed. Novel compounds $\mathbf{1 g}$ and $\mathbf{1 h}$ showed significant COX enzyme inhibition in liver cancer cells compared to DMSO controls.

future decisions regarding which derivatives to synthesize; this has been facilitated by the use of freely available descriptor generation and QSAR modeling software. The chemical applicability domain and the reliability of the predictions was validated via multiple statistical tests. A group of 3 descriptors identified sufficient structural features necessary to model assay activity. Molecular docking provided support for the hypothesis that these NSAIDderived compounds bind one or more of the COX enzymes, although activity via additional off-target effects cannot be ruled out. The docking also provided a plausible explanation for the unexpected lack of activity exhibited by one of the compounds. On the other hand the docking results decipher the induction of oxidative stress by these compounds.

The results we obtained in this study proposes novel triazolothiadiazine derived compounds can be good candidates for the treatment of epithelial cancers particularly liver cancer which has limited therapeutic options. 


\section{Materials and methods}

\subsection{Chemistry}

All chemicals were purchased from Sigma-Aldrich Chemical Co. (Steinheim, Germany). Melting points were detected with a Thomas Hoover capillary melting point apparatus (Philadelphia, PA, USA) and were uncorrected. IR spectra were recorded on a Perkin Elmer 1720X FT-IR spectrometer (Beaconsfield, UK) by direct sampling of the compounds and the results were expressed in wave numbers $\left(\mathrm{cm}^{-1}\right)$. Mass Spectra (MS) data were collected with a Waters Micromass ZQ LC-MS Spectrometer (Milford, MA, USA) instrument using the ESI (+) method. ${ }^{1} \mathrm{H}$ NMR spectra were taken on a Varian Mercury 400, a $400 \mathrm{MHz}$ High Performance Digital FT-NMR instrument (Varian, Palo Alto, CA, USA) in DMSO- $d_{6}$ or $\mathrm{CDCl}_{3}$ using TMS as internal standard. All chemical shift values were recorded as $\delta(\mathrm{ppm})$. Splitting patterns were as follows: s, singlet; d, doublet; dd, doublet of doublet; t, triplet; m, multiplet. Compound purity was checked by thin-layer chromatography on silica-gel-coated aluminum sheets (Merck, 1.005554, silica gel HF254-361, Type 60, 0.25 mm; Merck, Darmstadt, Germany). Elementary analyses of the resulting compounds were performed with Leco CHNS 932 analyzer at Ankara University, Faculty of Pharmacy Central II Laboratory and data were determined within $\pm 0.4 \%$ of the theoretical values. Microwave synthesis reactions were carried out using a Milestone Microsynth LabStation 1600 W (Monroe, CT, USA).

\subsubsection{Synthesis procedure of 4-amino-3-aryl-1,2,4-triazole-5- thiones (1-3)}

A mixture of equimolar amounts of aralkyl carboxylic acid (ibuprofen/naproxen/flurbiprofen) (10 mmol) and thiocarbohydrazide $(10 \mathrm{mmol})$ was heated in an oil bath at $160-170{ }^{\circ} \mathrm{C}$ for $1 \mathrm{~h}$. The resulting melted mass was triturated with hot water to obtain the compounds. The products were purified with column chromatography (n-hexane/ethyl acetate) (70:30).

4.1.1.1. 4-Amino-3-[1-[4-(2-methylpropyl)phenyl]ethyl]-1,2,4triazole-5-thione (1). Yield $0.95 \mathrm{~g}, 34 \% . \mathrm{Mp}: 161-163{ }^{\circ} \mathrm{C}(146-$ $\left.148{ }^{\circ} \mathrm{C}^{38}\right)$. IR: $v_{\max }$ : $3292(\mathrm{~N}-\mathrm{H}), 1632(\mathrm{C}=\mathrm{N}), 1167(\mathrm{C}=\mathrm{S}) \mathrm{cm}^{-1}$; ${ }^{1} \mathrm{H}$ NMR (DMSO-d $\left.d_{6}\right) \delta 0.89\left(6 \mathrm{H}, \mathrm{d}, J=6.4 \mathrm{~Hz},\left(\mathrm{CH}_{3}\right)_{2}-\mathrm{CH}-\right), 1.52$ $\left(3 \mathrm{H}, \mathrm{d}, \mathrm{J}=7.2 \mathrm{~Hz}, \mathrm{CH}_{3}-\mathrm{CH}-\right), 1.58\left(2 \mathrm{H}, \mathrm{s},-\mathrm{NH}_{2}\right), 1.82-1.85(1 \mathrm{H}, \mathrm{m}$, $\left.\left(\mathrm{CH}_{3}\right)_{2}-\mathrm{CH}-\mathrm{CH}_{2}-\right), 2.43\left(2 \mathrm{H}, \mathrm{d}, J=6.8 \mathrm{~Hz},-\mathrm{CH}^{-} \mathrm{CH}_{2}-\right), 3.59(1 \mathrm{H}, \mathrm{q}$, $\left.J=7.0 \mathrm{~Hz}, \mathrm{CH}_{3}-\mathrm{CH}-\right), 7.09-7.20(4 \mathrm{H}, \mathrm{m}, \operatorname{arom}),. 8.00(1 \mathrm{H}, \mathrm{d}$, $J=12.4 \mathrm{~Hz}, \mathrm{NH})$; MS (ESI+) $\mathrm{m} / z$ calcd for $\mathrm{C}_{14} \mathrm{H}_{21} \mathrm{~N}_{4} \mathrm{~S}(\mathrm{M}+\mathrm{H})^{+}$ 277.15, found: 277.10; Anal. Calcd for $\mathrm{C}_{14} \mathrm{H}_{20} \mathrm{~N}_{4} \mathrm{~S}$ : C, 60.84; $\mathrm{H}$, 7.29; N, 20.27; S, 11.60. Found: C, 61.08; H, 7.56; N, 20.19; S, 11.49.

4.1.1.2. 4-Amino-3-[1-(6-methoxynaphtalen-2-yl)ethyl]-1,2,4triazole-5-thione (2). Yield $1.62 \mathrm{~g}, 54 \%$ Mp: $216-218^{\circ} \mathrm{C}$ $\left(150-152{ }^{\circ} \mathrm{C}^{38}\right)$. IR: $v_{\max }: 3293(\mathrm{~N}-\mathrm{H}), 1634(\mathrm{C}=\mathrm{N}), 1167(\mathrm{C}=\mathrm{S})$ $\mathrm{cm}^{-1} ;{ }^{1} \mathrm{H}$ NMR (DMSO-d $) \delta 1.61\left(3 \mathrm{H}, \mathrm{d}, J=7.2 \mathrm{~Hz}, \mathrm{CH}_{3}-\mathrm{CH}-\right), 3.85$ $\left(3 \mathrm{H}, \mathrm{s}, \mathrm{OCH}_{3}\right), 4.48\left(1 \mathrm{H}, \mathrm{q}, J=7.2 \mathrm{~Hz}, \mathrm{CH}_{3}-\mathrm{CH}-\right), 5.44\left(2 \mathrm{H}, \mathrm{s},-\mathrm{NH}_{2}\right)$, $7.14(1 \mathrm{H}, \mathrm{dd}, J=8.8,2.8 \mathrm{~Hz}$, arom.), $7.29(1 \mathrm{H}, \mathrm{d}, J=2.8 \mathrm{~Hz}$, arom.), 7.39 ( $1 \mathrm{H}, \mathrm{dd}, J=8.2,2.0 \mathrm{~Hz}$, arom.), $7.78(3 \mathrm{H}, \mathrm{t}, J=8.8 \mathrm{~Hz}$, arom.), $13.62(1 \mathrm{H}, \mathrm{s}, \mathrm{NH})$; MS (ESI+) $\mathrm{m} / z$ calcd for $\mathrm{C}_{15} \mathrm{H}_{17} \mathrm{~N}_{4} \mathrm{OS}(\mathrm{M}+\mathrm{H})^{+}$ 301.11, found: 301.13; Anal. Calcd for $\mathrm{C}_{15} \mathrm{H}_{16} \mathrm{~N}_{4} \mathrm{OS} .1 / 4 \mathrm{CH}_{3}(\mathrm{C}=\mathrm{O})$ $\mathrm{OC}_{2} \mathrm{H}_{5}$ : C, 59.61; H, 5.63; N, 17.38; S, 9.94. Found: C, 60.02; H, 5.70; $\mathrm{N}, 16.96 ; \mathrm{S}, 9.51$.

4.1.1.3. 4-Amino-3-[1-(2-fluoro-1,1'-biphenyl-4-yl)ethyl]-1,2,4triazole-5-thione (3). Yield $1.20 \mathrm{~g}, 38 \%$. Mp: $205-207^{\circ} \mathrm{C}(169-$ $\left.170{ }^{\circ} \mathrm{C}^{38}\right)$. IR: $v_{\text {max }}$ : $3259(\mathrm{~N}-\mathrm{H}), 1621(\mathrm{C}=\mathrm{N}), 1153(\mathrm{C}=\mathrm{S}) \mathrm{cm}^{-1}$; ${ }^{1} \mathrm{H}$ NMR (DMSO-d $) \delta 1.64\left(3 \mathrm{H}, \mathrm{d}, J=7.2 \mathrm{~Hz}, \mathrm{CH}_{3}-\mathrm{CH}-\right), 3.73(1 \mathrm{H}$, q, $\left.J=6.4 \mathrm{~Hz}, \mathrm{CH}_{3}-\mathrm{CH}-\right), 4.47\left(2 \mathrm{H}, \mathrm{s},-\mathrm{NH}_{2}\right), 7.07-7.18(2 \mathrm{H}, \mathrm{m}$, arom.), 7.35-7.53 (6H, m, arom.), $10.96(1 \mathrm{H}, \mathrm{s}, \mathrm{NH})$; MS (ESI+) m/ $z$ calcd for $\mathrm{C}_{16} \mathrm{H}_{16} \mathrm{FN}_{4} \mathrm{~S}(\mathrm{M}+\mathrm{H})^{+} 315.11$, found: 315.11; Anal. Calcd for $\mathrm{C}_{16} \mathrm{H}_{15} \mathrm{FN}_{4} \mathrm{~S}$ : $\mathrm{C}, 61.13 ; \mathrm{H}, 4.81 ; \mathrm{N}, 17.82 ; \mathrm{S}, 10.20$. Found: $\mathrm{C}$, 60.77; H, 5.07; N, 17.54; S, 9.88 .

\subsubsection{Synthesis procedures of 3,6-disubstituted-1,2,4-triazolo [3,4-b]1,3,4-thiadiazines ( $1 \mathrm{a}-3 \mathbf{j})$.}

Conventional method: Compounds 1-3 (1 mmol) and corresponding phenacyl halogens $(1 \mathrm{mmol})$ were mixed in $20 \mathrm{~mL}$ of ethanol and refluxed. Reactions ended under control of TLC. The mixtures were then cooled to room temperature and precipitated with a hydroxylamine hydrochloride solution. Precipitates were purified with crystallization or column chromatography (chloroform/acetone).

Microwave irradiation: Compounds 1-3 (1 mmol) and corresponding phenacyl halogens $(1 \mathrm{mmol})$ were mixed in $10 \mathrm{~mL}$ of ethanol and refluxed under irradiation (350 Watt) for adequate durations. The mixtures were then cooled to room temperature and precipitated with hydroxylamine hydrochloride solution. Precipitates purified with crystallization from ethanol.

4.1.2.1. 3-[1-[4-(2-Methylpropyl)phenyl]ethyl]-6-phenyl-7H-1,2,4triazolo[3,4-b]-1,3,4-thiadiazine (1a). Yield $0.22 \mathrm{~g}, 59 \%(0.18 \mathrm{~g}$, $48 \%$ for MW). Mp: $143-144^{\circ} \mathrm{C}$. IR: $v_{\max }: 1600(\mathrm{C}=\mathrm{N}), 1310(\mathrm{C}-\mathrm{N})$ $\mathrm{cm}^{-1} ;{ }^{1} \mathrm{H}$ NMR (DMSO- $\left.d_{6}\right) \delta 0.82\left(6 \mathrm{H}, \mathrm{d}, J=6.8 \mathrm{~Hz},\left(\mathrm{CH}_{3}\right)_{2}-\mathrm{CH}-\right)$, $1.67\left(3 \mathrm{H}, \mathrm{d}, J=7.2 \mathrm{~Hz}, \mathrm{CH}_{3}-\mathrm{CH}-\right), 1.76-1.79\left(1 \mathrm{H}, \mathrm{m},\left(\mathrm{CH}_{3}\right)_{2}-\mathrm{CH}-\right.$ $\left.\mathrm{CH}_{2}-\right), 2.38\left(2 \mathrm{H}, \mathrm{d}, J=6.8 \mathrm{~Hz},-\mathrm{CH}_{-} \mathrm{CH}_{2}-\right), 4.29(1 \mathrm{H}, \mathrm{d}, J=16.0 \mathrm{~Hz}$, $\left.-\mathrm{S}-\mathrm{CH}_{2}\right), 4.40\left(1 \mathrm{H}, \mathrm{d}, J=15.6 \mathrm{~Hz},-\mathrm{S}-\mathrm{CH}_{2}\right), 4.54(1 \mathrm{H}, \mathrm{q}, J=6.8 \mathrm{~Hz}$, $\left.\mathrm{CH}_{3}-\mathrm{CH}-\right), 7.10(2 \mathrm{H}, \mathrm{d}, J=8.0 \mathrm{~Hz}$, arom. H-2, H-6), $7.23(2 \mathrm{H}, \mathrm{d}$, $J=8.0 \mathrm{~Hz}$, arom. $\mathrm{H}-3, \mathrm{H}-5), 7.51-7.61\left(3 \mathrm{H}, \mathrm{m}\right.$, arom. $\left.\mathrm{H}-3^{\prime}, 4^{\prime}, 5^{\prime}\right)$, $7.89\left(2 \mathrm{H}, \mathrm{d}, J=7.6 \mathrm{~Hz}\right.$, arom. $\left.\mathrm{H}-2^{\prime}, \mathrm{H}-6^{\prime}\right)$; MS (ESI+) $\mathrm{m} / z$ calcd for $\mathrm{C}_{22} \mathrm{H}_{25} \mathrm{~N}_{4} \mathrm{~S}(\mathrm{M}+\mathrm{H})^{+}$377.18, found: 377.19; Anal. Calcd for $\mathrm{C}_{22} \mathrm{H}_{24} \mathrm{~N}_{4} \mathrm{~S}$ : C, 70.18; H, 6.42; N, 14.88; S, 8.52. Found: C, 70.31; H, 6.30; N, 14.83; S, 8.61.

4.1.2.2. 3-[1-[4-(2-Methylpropyl)phenyl]ethyl]-6-(4-fluorophenyl)7H-1,2,4-triazolo[3,4-b]-1,3,4-thiadiazine (1b). Yield $0.35 \mathrm{~g}, 89 \%$ $(0.22 \mathrm{~g}, 57 \%$ for $\mathrm{MW})$. Mp: $148-150^{\circ} \mathrm{C}$. IR: $v_{\max }$ : $1600(\mathrm{C}=\mathrm{N})$, $1313(\mathrm{C}-\mathrm{N}) \mathrm{cm}^{-1} ;{ }^{1} \mathrm{H}$ NMR (DMSO-d $\left.d_{6}\right) \delta 0.82(6 \mathrm{H}, \mathrm{d}, J=6.8 \mathrm{~Hz}$, $\left.\left(\mathrm{CH}_{3}\right)_{2}-\mathrm{CH}-\right), 1.67\left(3 \mathrm{H}, \mathrm{d}, J=7.6 \mathrm{~Hz}, \mathrm{CH}_{3}-\mathrm{CH}-\right), 1.76-1.79(1 \mathrm{H}, \mathrm{m}$, $\left.\left(\mathrm{CH}_{3}\right)_{2}-\mathrm{CH}-\mathrm{CH}_{2}-\right), 2.38\left(2 \mathrm{H}, \mathrm{d}, J=6.8 \mathrm{~Hz},-\mathrm{CH}-\mathrm{CH}_{2}-\right), 4.29(1 \mathrm{H}, \mathrm{d}$, $\left.J=15.6 \mathrm{~Hz},-\mathrm{S}-\mathrm{CH}_{2}\right), 4.39\left(1 \mathrm{H}, \mathrm{d}, J=16.0 \mathrm{~Hz},-\mathrm{S}-\mathrm{CH}_{2}\right), 4.54(1 \mathrm{H}, \mathrm{q}$, $\left.J=6.8 \mathrm{~Hz}, \mathrm{CH}_{3}-\mathrm{CH}-\right), 7.10(2 \mathrm{H}, \mathrm{d}, J=8.4 \mathrm{~Hz}$, arom. $\mathrm{H}-2, \mathrm{H}-6), 7.23$ $(2 \mathrm{H}, \mathrm{d}, J=7.6 \mathrm{~Hz}$, arom. H-3, H-5), $7.40(2 \mathrm{H}, \mathrm{t}, J=8.8 \mathrm{~Hz}$, arom. $\left.\mathrm{H}-3^{\prime}, \mathrm{H}-5^{\prime}\right), 7.95-7.99$ (2H, m, arom. H-2', H-6'); MS (ESI+) $m / z$ calcd for $\mathrm{C}_{22} \mathrm{H}_{24} \mathrm{FN}_{4} \mathrm{~S}(\mathrm{M}+\mathrm{H})^{+}$395.17, found: 395.19; Anal. Calcd for $\mathrm{C}_{22} \mathrm{H}_{23} \mathrm{FN}_{4} \mathrm{~S}$ : C, 66.98; $\mathrm{H}, 5.88 ; \mathrm{N}, 14.20 ; \mathrm{S}, 8.13$. Found: $\mathrm{C}, 66.84$; $\mathrm{H}, 5.67$; N, 14.08; S, 8.26.

\subsubsection{3-[1-[4-(2-Methylpropyl)phenyl]ethyl]-6-(4-chlorophe-} nyl)-7H-1,2,4-triazolo[3,4-b]-1,3,4-thiadiazine (1c). Yield $0.29 \mathrm{~g}$, $70 \%\left(0.34 \mathrm{~g}, 81 \%\right.$ for MW). Mp: $158-159{ }^{\circ} \mathrm{C}$. IR: $v_{\max }: 1592(\mathrm{C}=\mathrm{N})$, $1321(\mathrm{C}-\mathrm{N}) \mathrm{cm}^{-1} ;{ }^{1} \mathrm{H}$ NMR (DMSO-d $\left.{ }_{6}\right) \delta 0.81(6 \mathrm{H}, \mathrm{d}, J=6.4 \mathrm{~Hz}$, $\left.\left(\mathrm{CH}_{3}\right)_{2}-\mathrm{CH}-\right), 1.67\left(3 \mathrm{H}, \mathrm{d}, J=7.6 \mathrm{~Hz}, \mathrm{CH}_{3}-\mathrm{CH}-\right), 1.76-1.79(1 \mathrm{H}, \mathrm{m}$, $\left.\left(\mathrm{CH}_{3}\right)_{2}-\mathrm{CH}-\mathrm{CH}_{2}-\right), 2.38\left(2 \mathrm{H}, \mathrm{d}, J=6.8 \mathrm{~Hz},-\mathrm{CH}-\mathrm{CH}_{2}-\right), 4.29(1 \mathrm{H}, \mathrm{d}$, $\left.J=15.6 \mathrm{~Hz},-\mathrm{S}-\mathrm{CH}_{2}\right), 4.39\left(1 \mathrm{H}, \mathrm{d}, J=15.6 \mathrm{~Hz},-\mathrm{S}-\mathrm{CH}_{2}\right), 4.53(1 \mathrm{H}, \mathrm{q}$, $\left.J=6.8 \mathrm{~Hz}, \mathrm{CH}_{3}-\mathrm{CH}-\right), 7.09(2 \mathrm{H}, \mathrm{d}, J=8.4 \mathrm{~Hz}$, arom. H-2, H-6), 7.23 $(2 \mathrm{H}, \mathrm{d}, J=7.6 \mathrm{~Hz}$, arom. $\mathrm{H}-3, \mathrm{H}-5), 7.62(2 \mathrm{H}, \mathrm{d}, J=8.8 \mathrm{~Hz}$, arom. $\left.\mathrm{H}-2^{\prime}, \mathrm{H}-6^{\prime}\right), 7.92(2 \mathrm{H}, \mathrm{d}, J=8.8 \mathrm{~Hz}$, arom. H-3', H-5'); MS (ESI+) $m / z$ calcd for $\mathrm{C}_{22} \mathrm{H}_{24} \mathrm{ClN}_{4} \mathrm{~S}(\mathrm{M}+\mathrm{H})^{+}$411.14, found: 411.18; Anal. Calcd for $\mathrm{C}_{22} \mathrm{H}_{23} \mathrm{ClN}_{4} \mathrm{~S}$ : C, 64.30; H, 5.64; N, 13.63; S, 7.80. Found: C, 64.16; H, 5.74; N, 13.38; S, 7.77. 
4.1.2.4. 3-[1-[4-(2-Methylpropyl)phenyl]ethyl]-6-(2,4-dichlorophenyl)-7H-1,2,4-triazolo[3,4-b]-1,3,4-thiadiazine (1d). Yield $0.37 \mathrm{~g}, 83 \%$ (0.15 g, $34 \%$ for MW). Mp: $150-151^{\circ} \mathrm{C}$. IR: $v_{\max }: 1583$ $(\mathrm{C}=\mathrm{N}), 1311(\mathrm{C}-\mathrm{N}) \mathrm{cm}^{-1} ;{ }^{1} \mathrm{H}$ NMR $\left(\mathrm{CDCl}_{3}\right) \delta 0.88(6 \mathrm{H}, \mathrm{d}, J=6.4 \mathrm{~Hz}$, $\left.\left(\mathrm{CH}_{3}\right)_{2}-\mathrm{CH}-\right), 1.80\left(3 \mathrm{H}, \mathrm{d}, \mathrm{J}=6.8 \mathrm{~Hz}, \mathrm{CH}_{3}-\mathrm{CH}-\right), 1.83-1.87(1 \mathrm{H}, \mathrm{m}$, $\left.\left(\mathrm{CH}_{3}\right)_{2}-\mathrm{CH}-\mathrm{CH}_{2}-\right), 2.44\left(2 \mathrm{H}, \mathrm{d}, J=7.2 \mathrm{~Hz},-\mathrm{CH}_{-} \mathrm{CH}_{2}-\right), 3.72(1 \mathrm{H}, \mathrm{d}$, $\left.J=15.6 \mathrm{~Hz},-\mathrm{S}-\mathrm{CH}_{2}\right), 3.85\left(1 \mathrm{H}, \mathrm{d}, J=15.2 \mathrm{~Hz},-\mathrm{S}-\mathrm{CH}_{2}\right), 4.44(1 \mathrm{H}, \mathrm{q}$, $\left.J=7.6 \mathrm{~Hz}, \mathrm{CH}_{3}-\mathrm{CH}-\right), 7.07(2 \mathrm{H}, \mathrm{d}, J=8.0 \mathrm{~Hz}$, arom. $\mathrm{H}-2, \mathrm{H}-6), 7.20$ $(2 \mathrm{H}, \mathrm{t}, J=7.6 \mathrm{~Hz}$, arom. H-5', H-6') $7.33-7.35$ (2H, m, arom. H-3, H5), $7.51\left(1 \mathrm{H}, \mathrm{d}, J=2.0 \mathrm{~Hz}\right.$, arom $\left.\mathrm{H}-3^{\prime}\right)$; MS (ESI+) $\mathrm{m} / z$ calcd for $\mathrm{C}_{22} \mathrm{H}_{23^{-}}$ $\mathrm{Cl}_{2} \mathrm{~N}_{4} \mathrm{~S}(\mathrm{M}+\mathrm{H})^{+} 445.10$, found: 445.16; Anal. Calcd for $\mathrm{C}_{22} \mathrm{H}_{22} \mathrm{Cl}_{2} \mathrm{~N}_{4} \mathrm{~S}$ : C, 59.33; H, 4.98; N, 12.58; S, 7.20. Found: C, 59.58; H, 4.76; N, 12.75; S, 7.28 .

4.1.2.5. 3-[1-[4-(2-Methylpropyl)phenyl]ethyl]-6-(4-bromophenyl)7H-1,2,4-triazolo[3,4-b]-1,3,4-thiadiazine (1e). Yield $0.27 \mathrm{~g}, 58 \%$ $\left(0.34 \mathrm{~g}, 73 \%\right.$ for MW). Mp: $159-160^{\circ} \mathrm{C}$. IR: $v_{\max }: 1586(\mathrm{C}=\mathrm{N}), 1321$ $(\mathrm{C}-\mathrm{N}) \mathrm{cm}^{-1} ;{ }^{1} \mathrm{H}$ NMR $\left(\mathrm{CDCl}_{3}\right) \delta 0.86\left(6 \mathrm{H}, \mathrm{d}, J=6.8 \mathrm{~Hz},\left(\mathrm{CH}_{3}\right)_{2}-\mathrm{CH}-\right)$, 1.78-1.84 (1H, m, $\left.\left(\mathrm{CH}_{3}\right)_{2}-\mathrm{CH}-\mathrm{CH}_{2}-\right), 1.82\left(3 \mathrm{H}, \mathrm{d}, J=7.6 \mathrm{~Hz}, \mathrm{CH}_{3}-\mathrm{CH}-\right)$, $2.41\left(2 \mathrm{H}, \mathrm{d}, J=7.2 \mathrm{~Hz},-\mathrm{CH}-\mathrm{CH}_{2}-\right), 3.77\left(1 \mathrm{H}, \mathrm{d}, J=15.6 \mathrm{~Hz},-\mathrm{S}-\mathrm{CH}_{2}\right)$, $3.90\left(1 \mathrm{H}, \mathrm{d}, J=15.6 \mathrm{~Hz},-\mathrm{S}-\mathrm{CH}_{2}\right), 4.49\left(1 \mathrm{H}, \mathrm{q}, J=7.2 \mathrm{~Hz}, \mathrm{CH}_{3}-\mathrm{CH}-\right)$, $7.06(2 \mathrm{H}, \mathrm{d}, J=8.0 \mathrm{~Hz}$, arom. H-2, H-6), $7.24(2 \mathrm{H}, \mathrm{d}, J=8.0 \mathrm{~Hz}$, arom. H-3, H-5), 7.61 (4H, s, arom. H-2', H-3', H-5', H-6'); MS (ESI+) m/z calcd for $\mathrm{C}_{22} \mathrm{H}_{24} \mathrm{BrN}_{4} \mathrm{~S}(\mathrm{M}+\mathrm{H})^{+}$455.09, found: 455.15; Anal. Calcd for $\mathrm{C}_{22} \mathrm{H}_{23}$ $\mathrm{BrN}_{4} \mathrm{~S}$ : C, 58.02; H, 5.09; N, 12.30; S, 7.04. Found: C, 57.73; H, 5.09; N, 12.29; S, 7.24.

4.1.2.6. 3-[1-[4-(2-Methylpropyl)phenyl]ethyl]-6-(4-nitrophenyl)7H-1,2,4-triazolo-[3,4-b]-1,3,4-thiadiazine (1f). Yield $0.36 \mathrm{~g}$, $84 \%\left(0.34 \mathrm{~g}, 80 \%\right.$ for MW). Mp: $152-153^{\circ} \mathrm{C}$. IR: $v_{\max }: 1600(\mathrm{C}=\mathrm{N})$, $1347(\mathrm{C}-\mathrm{N}) \mathrm{cm}^{-1} ;{ }^{1} \mathrm{H}$ NMR $\left(\mathrm{CDCl}_{3}\right) \delta 0.86(6 \mathrm{H}, \mathrm{d}, J=6.8 \mathrm{~Hz}$, $\left.\left(\mathrm{CH}_{3}\right)_{2}-\mathrm{CH}-\right), 1.79-1.81\left(1 \mathrm{H}, \mathrm{m},\left(\mathrm{CH}_{3}\right)_{2}-\mathrm{CH}_{-} \mathrm{CH}_{2}-\right), 1.84(3 \mathrm{H}, \mathrm{d}$, $\left.J=7.6 \mathrm{~Hz}, \mathrm{CH}_{3}-\mathrm{CH}-\right), 2.42\left(2 \mathrm{H}, \mathrm{d}, J=6.8 \mathrm{~Hz},-\mathrm{CH}_{-} \mathrm{CH}_{2}-\right), 3.86(1 \mathrm{H}$, $\left.\mathrm{d}, J=15.6 \mathrm{~Hz},-\mathrm{S}-\mathrm{CH}_{2}\right), 3.98\left(1 \mathrm{H}, \mathrm{d}, J=15.2 \mathrm{~Hz},-\mathrm{S}_{-} \mathrm{CH}_{2}\right), 4.49(1 \mathrm{H}$, q, $\left.J=7.2 \mathrm{~Hz}, \mathrm{CH}_{3}-\mathrm{CH}-\right), 7.08(2 \mathrm{H}, \mathrm{d}, J=8.4 \mathrm{~Hz}$, arom. $\mathrm{H}-2, \mathrm{H}-6)$, $7.23(2 \mathrm{H}, \mathrm{d}, J=7.6 \mathrm{~Hz}$, arom. H-3, H-5), $7.90(2 \mathrm{H}, \mathrm{d}, J=8.8 \mathrm{~Hz}$, arom. $\left.\mathrm{H}-2^{\prime}, \mathrm{H}-6^{\prime}\right), 8.33\left(2 \mathrm{H}, \mathrm{d}\right.$, arom. $J=8.8 \mathrm{~Hz}, \mathrm{H}-3^{\prime}, \mathrm{H}-5^{\prime}$ ); MS (ESI+) $m / z$ calcd for $\mathrm{C}_{22} \mathrm{H}_{24} \mathrm{~N}_{5} \mathrm{O}_{2} \mathrm{~S}(\mathrm{M}+\mathrm{H})^{+}$422.17, found: 422.20; Anal. Calcd for $\mathrm{C}_{22} \mathrm{H}_{23} \mathrm{~N}_{5} \mathrm{O}_{2} \mathrm{~S}$ : C, 62.69; $\mathrm{H}, 5.50 ; \mathrm{N}, 16.61 ; \mathrm{S}, 7.61$. Found: C, 62.36; H, 5.53; N, 16.53; S, 7.57 .

4.1.2.7. 3-[1-[4-(2-Methylpropyl)phenyl]ethyl]-6-(4-methylphenyl)-7H-1,2,4-triazolo[3,4-b]-1,3,4-thiadiazine (1g). Yield $0.1 \mathrm{~g}, 25 \%\left(0.31 \mathrm{~g}, 77 \%\right.$ for MW). Mp: $185-186{ }^{\circ} \mathrm{C}$. IR: $v_{\max }: 1598$ $(\mathrm{C}=\mathrm{N}), 1316(\mathrm{C}-\mathrm{N}) \mathrm{cm}^{-1} ;{ }^{1} \mathrm{H}$ NMR $\left(\mathrm{CDCl}_{3}\right) \delta 0.86(6 \mathrm{H}, \mathrm{d}$, $\left.J=6.8 \mathrm{~Hz},\left(\mathrm{CH}_{3}\right)_{2}-\mathrm{CH}-\right), 1.79-1.84\left(1 \mathrm{H}, \mathrm{m},\left(\mathrm{CH}_{3}\right)_{2}-\mathrm{CH}-\mathrm{CH}_{2}-\right), 1.83$ $\left(3 \mathrm{H}, \mathrm{d}, J=7.6 \mathrm{~Hz}, \mathrm{CH}_{3}-\mathrm{CH}-\right), 2.41\left(2 \mathrm{H}, \mathrm{d}, J=7.6 \mathrm{~Hz},-\mathrm{CH}_{-}-\mathrm{CH}_{2^{-}}\right)$, $2.43\left(3 \mathrm{H}, \mathrm{s},-\mathrm{CH}_{3}\right), 3.77\left(1 \mathrm{H}, \mathrm{d}, J=15.6 \mathrm{~Hz},-\mathrm{S}-\mathrm{CH}_{2}\right), 3.91(1 \mathrm{H}, \mathrm{d}$, $\left.J=15.2 \mathrm{~Hz},-\mathrm{S}-\mathrm{CH}_{2}\right), 4.52\left(1 \mathrm{H}, \mathrm{q}, J=7.6 \mathrm{~Hz}, \mathrm{CH}_{3}-\mathrm{CH}-\right), 7.06(2 \mathrm{H}, \mathrm{d}$, $J=7.6 \mathrm{~Hz}$, arom. H-2, H-6), $7.27(4 \mathrm{H}, \mathrm{m}$, arom. H-3, H-5, H-3', H$\left.5^{\prime}\right), 7.66(2 \mathrm{H}, \mathrm{d}, J=8.0 \mathrm{~Hz}$, arom. H-2', H-6'); MS (ESI+) $\mathrm{m} / z$ calcd for $\mathrm{C}_{23} \mathrm{H}_{27} \mathrm{~N}_{4} \mathrm{~S}(\mathrm{M}+\mathrm{H})^{+}$391.20, found: 391.20, Anal. Calcd for $\mathrm{C}_{23} \mathrm{H}_{26} \mathrm{~N}_{4} \mathrm{~S} . \mathrm{H}_{2} \mathrm{O}$ : C, 67.62; H, 6.91; N, 13.71; S, 7.85. Found: C, $67.92 ; \mathrm{H}, 6.44 ; \mathrm{N}, 14.27 ; \mathrm{S}, 7.87$.

4.1.2.8. 3-[1-[4-(2-Methylpropyl)phenyl]ethyl]-6-(4-methoxyphenyl)-7H-1,2,4-triazolo[3,4-b]-1,3,4-thiadiazine (1h). Yield $0.19 \mathrm{~g}$, $46 \%\left(0.22 \mathrm{~g}, 52 \%\right.$ for MW). Mp: $184-185^{\circ} \mathrm{C}$. IR: $v_{\max }: 1605(\mathrm{C}=\mathrm{N})$, $1316(\mathrm{C}-\mathrm{N}), 1256(\mathrm{C}-\mathrm{O}) \mathrm{cm}^{-1} ;{ }^{1} \mathrm{H}$ NMR $\left(\mathrm{CDCl}_{3}\right) \delta 0.86(6 \mathrm{H}, \mathrm{d}$, $\left.J=6.8 \mathrm{~Hz},\left(\mathrm{CH}_{3}\right)_{2}-\mathrm{CH}-\right), 1.79-1.81\left(1 \mathrm{H}, \mathrm{m},\left(\mathrm{CH}_{3}\right)_{2}-\mathrm{CH}-\mathrm{CH}_{2}-\right), 1.82$ $\left(3 \mathrm{H}, \mathrm{d}, J=7.6 \mathrm{~Hz}, \mathrm{CH}_{3}-\mathrm{CH}-\right), 2.40\left(2 \mathrm{H}, \mathrm{d}, J=7.2 \mathrm{~Hz},-\mathrm{CH}_{-} \mathrm{CH}_{2}-\right)$, $3.75\left(1 \mathrm{H}, \mathrm{d}, J=15.2 \mathrm{~Hz},-\mathrm{S}-\mathrm{CH}_{2}\right), 3.90\left(1 \mathrm{H}, \mathrm{d}, J=14.0 \mathrm{~Hz},-\mathrm{S}-\mathrm{CH}_{2}\right)$, $3.88\left(3 \mathrm{H}, \mathrm{s},-\mathrm{OCH}_{3}\right), 4.52\left(1 \mathrm{H}, \mathrm{q}, J=7.2 \mathrm{~Hz}, \mathrm{CH}_{3}-\mathrm{CH}-\right), 6.97(2 \mathrm{H}, \mathrm{d}$, $J=8.8 \mathrm{~Hz}$, arom. H-3', H-5') $7.06(2 \mathrm{H}, \mathrm{d}, J=7.6 \mathrm{~Hz}$, arom. $\mathrm{H}-2$,
$\mathrm{H}-6), 7.26(2 \mathrm{H}, \mathrm{d}, J=7.6 \mathrm{~Hz}$, arom. H-3, H-5), $7.73(2 \mathrm{H}, \mathrm{d}$, $J=8.8 \mathrm{~Hz}$, arom. H-2', H-6'); ${ }^{13} \mathrm{C}$ NMR $\left(\mathrm{CDCl}_{3}\right) \delta 20.06\left(\mathrm{CH}_{3}-\mathrm{CH}-\right)$, $22.05\left(\left(\mathrm{CH}_{3}\right)_{2} \mathrm{CH}-\right), 22.39\left(\left(\mathrm{CH}_{3}\right)_{2}-\mathrm{CH}_{-}-\mathrm{CH}_{2}-\right), 29.47\left(-\mathrm{CH}-\mathrm{CH}_{2}-\right)$, $35.11\left(-\mathrm{SCH}_{2}-\right), 44.09\left(\mathrm{CH}_{3}-\mathrm{CH}-\right), 55.44\left(-\mathrm{OCH}_{3}\right), 114.31$ (arom. C-3', C-5'), 125.47 (arom. C-4), 126.98 (arom. C-2, C-6), 128.96 (arom. C-3, C-5), 129.13 (arom. C-1'), 139.37 (arom. C-1), 139.45 (arom. C-2', C-6'), 153.66 (arom. C-4'), 140.19 (C-8a), 155.57 (C3), 162.08 (C-6); MS (ESI+) $m / z$ calcd for $\mathrm{C}_{23} \mathrm{H}_{27} \mathrm{~N}_{4} \mathrm{OS}(\mathrm{M}+\mathrm{H})^{+}$ 407.19, found: 407.22; Anal. Calcd for $\mathrm{C}_{23} \mathrm{H}_{26} \mathrm{~N}_{4} \mathrm{OS}$ : C, 67.95; $\mathrm{H}$ 6.45; N, 13.78; S, 7.89. Found: C, 68.09; H, 6.65; N, 13.39; S, 7.75.

4.1.2.9. 3-[1-[4-(2-Methylpropyl)phenyl]ethyl]-6-(4-trifluoromethylphenyl)-7H-1,2,4-triazolo[3,4-b]-1,3,4-thiadiazine (1i). Yield $0.15 \mathrm{~g}, 32 \%\left(0.29 \mathrm{~g}, 61 \%\right.$ for MW). Mp: $176-178^{\circ} \mathrm{C}$. IR: $v_{\max }$ : $1618(\mathrm{C}=\mathrm{N}), 1310(\mathrm{C}-\mathrm{N}) \mathrm{cm}^{-\mathbf{1}} ;{ }^{\mathbf{1}} \mathrm{H}$ NMR $\left(\mathrm{CDCl}_{\mathbf{3}}\right) \boldsymbol{\delta} 0.86(6 \mathrm{H}, \mathrm{d}$, $\left.\boldsymbol{J}=6.8 \mathrm{~Hz},\left(\mathrm{CH}_{3}\right)_{2}-\mathrm{CH}-\right), 1.81\left(1 \mathrm{H}, \mathrm{m},\left(\mathrm{CH}_{3}\right)_{2}-\mathrm{CH}^{-} \mathrm{CH}_{2^{-}}\right), 1.92(3 \mathrm{H}, \mathrm{d}$, $\left.\boldsymbol{J}=6.8 \mathrm{~Hz}, \mathrm{CH}_{3^{-}}-\mathrm{CH}-\right), 2.43\left(2 \mathrm{H}, \mathrm{d}, \boldsymbol{J}=7.2 \mathrm{~Hz},-\mathrm{CH}-\mathrm{CH}_{2^{-}}\right), 4.30(1 \mathrm{H}, \mathrm{q}$, $\left.\mathrm{CH}_{3}-\mathrm{CH}-\right), 4.70\left(2 \mathrm{H}, \mathrm{d}, \boldsymbol{J}=6.8 \mathrm{~Hz},-\mathrm{S}-\mathrm{CH}_{2}\right), 7.12(2 \mathrm{H}, \mathrm{d}, \boldsymbol{J}=8.0 \mathrm{~Hz}, \mathrm{H}-2$ H-6), 7.28 (2H, d, J = 8.0 Hz, H-3, H-5), 7.78 (2H, d, $\boldsymbol{J}=8.0 \mathrm{~Hz}, \mathrm{H}-2^{\prime}, \mathrm{H}-$ $\left.6^{\prime}\right), 7.98\left(2 \mathrm{H}, \mathrm{d}, \boldsymbol{J}=8.0 \mathrm{~Hz}, \mathrm{H}-3^{\prime}, \mathrm{H}-5^{\prime}\right)$; MS (ESI+) $\boldsymbol{m} / \boldsymbol{z}$ calcd for $\mathrm{C}_{23^{-}}$ $\mathrm{H}_{24} \mathrm{~F}_{3} \mathrm{~N}_{4} \mathrm{~S}(\mathrm{M}+\mathrm{H})^{+} 445.17$, found: 445.14; Anal. Calcd for $\mathrm{C}_{23} \mathrm{H}_{23} \mathrm{~F}_{3} \mathrm{~N}_{4} \mathrm{~S}$ : C, 62.15; H, 5.22; N, 12.60; S, 7.21. Found: C, 61.92; H, 5.21; N, 12.65; S, 7.30.

4.1.2.10. 3-[1-[4-(2-Methylpropyl)phenyl]ethyl]-6-(4-trifluoromethoxyphenyl)-7 H-1,2,4-triazolo[3,4-b]-1,3,4-thiadiazine (1j). Yield $0.12 \mathrm{~g}, 27 \%(0.29 \mathrm{~g}, 65 \%$ for $\mathrm{MW})$. Mp: $132-133{ }^{\circ} \mathrm{C}$. IR: $v_{\max }$ : $1596(\mathrm{C}=\mathrm{N}), 1362(\mathrm{C}-\mathrm{N}), 1297(\mathrm{C}-\mathrm{O}) \mathrm{cm}^{-1} ;{ }^{1} \mathrm{H}$ NMR $\left(\mathrm{CDCl}_{3}\right) \delta 0.86\left(6 \mathrm{H}, \mathrm{d}, J=6.4 \mathrm{~Hz},\left(\mathrm{CH}_{3}\right)_{2}-\mathrm{CH}-\right), 1.79-1.82(1 \mathrm{H}, \mathrm{m}$, $\left.\left(\mathrm{CH}_{3}\right)_{2}-\mathrm{CH}-\mathrm{CH}_{2}-\right), 1.83\left(3 \mathrm{H}, \mathrm{d}, J=7.2 \mathrm{~Hz}, \mathrm{CH}_{3}-\mathrm{CH}-\right), 2.42(2 \mathrm{H}, \mathrm{d}$, $\left.J=7.2 \mathrm{~Hz},-\mathrm{CH}-\mathrm{CH}_{2}-\right), 3.79\left(1 \mathrm{H}, \mathrm{d}, J=15.6 \mathrm{~Hz},-\mathrm{S}-\mathrm{CH}_{2}\right), 3.92(1 \mathrm{H}$ d, $\left.J=15.6 \mathrm{~Hz},-\mathrm{S}-\mathrm{CH}_{2}\right), 4.49\left(1 \mathrm{H}, \mathrm{q}, J=6.8 \mathrm{~Hz}, \mathrm{CH}_{3}-\mathrm{CH}-\right), 7.07(2 \mathrm{H}$, d, $J=8.0 \mathrm{~Hz}$, arom. H-2, H-6), $7.24(2 \mathrm{H}, \mathrm{d}, J=7.6 \mathrm{~Hz}$, arom. $\mathrm{H}-3$, $\mathrm{H}-5), 7.32\left(2 \mathrm{H}, \mathrm{d}, J=7.6 \mathrm{~Hz}\right.$, arom. $\left.\mathrm{H}^{\prime} 2^{\prime}, \mathrm{H}-6^{\prime}\right), 7.78(2 \mathrm{H}, \mathrm{d}$ $J=8.8 \mathrm{~Hz}$, arom. $\mathrm{H}-3^{\prime}, \mathrm{H}-5^{\prime}$ ); MS (ESI+) $m / z$ calcd for $\mathrm{C}_{23} \mathrm{H}_{24} \mathrm{~F}_{3} \mathrm{~N}_{4} \mathrm{OS}$ $(\mathrm{M}+\mathrm{H})^{+}$461.16, found: 461.16; Anal. Calcd for $\mathrm{C}_{23} \mathrm{H}_{23} \mathrm{~F}_{3} \mathrm{~N}_{4} \mathrm{OS} .1 / 4$ $\mathrm{H}_{2} \mathrm{O}$ C, 59.41; H, 5.09; N, 12.05; S, 6.89. Found: C, 59.32; H, 4.74; $\mathrm{N}, 12.13 ; \mathrm{S}, 6.92$.

4.1.2.11. 3-[1-(6-Methoxynaphtalen-2-yl)ethyl]-6-phenyl-7H1,2,4-triazolo[3,4-b]-1,3,4-thiadiazine (2a). Yield $0.31 \mathrm{~g}, 77 \%$ (0.21 g, 52\% for MW). Mp: 199-200. IR: $v_{\max }: 1605(\mathrm{C}=\mathrm{N}), 1308$ $(\mathrm{C}-\mathrm{N}), 1262(\mathrm{C}-\mathrm{O}) \mathrm{cm}^{-1} ;{ }^{1} \mathrm{H}$ NMR (DMSO-d $\left.)_{6}\right) 1.77(3 \mathrm{H}, \mathrm{d}$, $\left.J=7.2 \mathrm{~Hz}, \mathrm{CH}_{3}-\mathrm{CH}-\right), 3.84\left(3 \mathrm{H}, \mathrm{s}, \mathrm{OCH}_{3}\right), 4.26(1 \mathrm{H}, \mathrm{d}, J=15.6 \mathrm{~Hz},-$ $\left.\mathrm{S}-\mathrm{CH}_{2}\right), 4.39\left(1 \mathrm{H}, \mathrm{d}, J=16.0 \mathrm{~Hz},-\mathrm{S}-\mathrm{CH}_{2}\right), 4.71(1 \mathrm{H}, \mathrm{q}, J=7.2 \mathrm{~Hz}$, $\left.\mathrm{CH}_{3}-\mathrm{CH}-\right), 7.13(1 \mathrm{H}, \mathrm{dd}, J=9.2,2.4 \mathrm{~Hz}$, arom. $\mathrm{H}), 7.26(1 \mathrm{H}, \mathrm{s}$, arom. $\mathrm{H}), 7.44-7.58(4 \mathrm{H}, \mathrm{m}$, arom. $\mathrm{H}), 7.78\left(3 \mathrm{H}, \mathrm{t}, J=9.6 \mathrm{~Hz}\right.$, arom. $\mathrm{H}-3^{\prime}$, $\left.\mathrm{H}-4^{\prime}, \mathrm{H}-5^{\prime}\right), 7.90(2 \mathrm{H}, \mathrm{d}, J=7.2 \mathrm{~Hz}$, arom. H-2', H-6'); MS (ESI+) $m / z$ calcd for $\mathrm{C}_{23} \mathrm{H}_{21} \mathrm{~N}_{4} \mathrm{OS}(\mathrm{M}+\mathrm{H})^{+}$401.14, found: 401.17; Anal. Calcd for $\mathrm{C}_{23} \mathrm{H}_{20} \mathrm{~N}_{4} \mathrm{OS}$ : $\mathrm{C}, 68.98 ; \mathrm{H}, 5.03 ; \mathrm{N}, 13.99 ; \mathrm{S}, 8.01$. Found: $\mathrm{C}$ 69.42; H, 5.12; N, 13.94; S, 8.13.

4.1.2.12. 3-[1-(6-Methoxynaphtalen-2-yl)ethyl]-6-(4-fluorophenyl)7H-1,2,4-triazolo[3,4-b]-1,3,4-thiadiazine (2b). Yield $0.39 \mathrm{~g}$, $92 \%(0.20 \mathrm{~g}, 47 \%$ for $\mathrm{MW})$. Mp.: $187-189{ }^{\circ} \mathrm{C}$. IR: $v_{\max }: 1603$ $(\mathrm{C}=\mathrm{N}), 1303(\mathrm{C}-\mathrm{N}), 1261(\mathrm{C}-\mathrm{O}) \mathrm{cm}^{-1} ;{ }^{1} \mathrm{H}$ NMR $\left(\right.$ DMSO-d $\left.\mathrm{d}_{6}\right) \delta$ $1.76\left(3 \mathrm{H}, \mathrm{d}, J=6.8 \mathrm{~Hz}, \mathrm{CH}_{3}-\mathrm{CH}-\right), 3.84\left(3 \mathrm{H}, \mathrm{s}, \mathrm{OCH}_{3}\right), 4.25(1 \mathrm{H}, \mathrm{d}$, $\left.J=16.0 \mathrm{~Hz},-\mathrm{S}-\mathrm{CH}_{2}\right), 4.39\left(1 \mathrm{H}, \mathrm{d}, J=16.0 \mathrm{~Hz},-\mathrm{S}-\mathrm{CH}_{2}\right), 4.71(1 \mathrm{H}, \mathrm{q}$, $\left.J=6.8 \mathrm{~Hz}, \mathrm{CH}_{3}-\mathrm{CH}-\right), 7.13(1 \mathrm{H}$, dd, $J=8.8,2.8 \mathrm{~Hz}$, arom. $\mathrm{H}), 7.26$ $(1 \mathrm{H}, \mathrm{s}$, arom. H), 7.36-7.47 $(3 \mathrm{H}, \mathrm{m}$, arom. $\mathrm{H}), 7.78(3 \mathrm{H}, \mathrm{t}$, $J=9.2 \mathrm{~Hz}$, arom. H), 7.96-8.00 (2H, m, arom. H-2', H-6'); MS (ESI +) $\mathrm{m} / z$ calcd for $\mathrm{C}_{23} \mathrm{H}_{19} \mathrm{FN}_{4} \mathrm{OS}(\mathrm{M}+\mathrm{H})^{+} 441.12$, found 441.17; Anal. Calcd for $\mathrm{C}_{23} \mathrm{H}_{19} \mathrm{FN}_{4} \mathrm{OS}$ : C, 66.01; $\mathrm{H}, 4.58 ; \mathrm{N}, 13.39 ; \mathrm{S}, 7.66$. Found: C, 66.16; H, 4.42; N, 13.26; S, 7.71. 
4.1.2.13. 3-[1-(6-Methoxynaphtalen-2-yl)ethyl]-6-(4-chlorophenyl)-7H-1,2,4-triazolo[3,4-b]-1,3,4-thiadiazine (2c). Yield $0.10 \mathrm{~g}, 25 \%$ (0.36 g, $90 \%$ for MW). Mp: $160-161^{\circ} \mathrm{C}$. IR: $v_{\max }: 1603$ $(\mathrm{C}=\mathrm{N}), 1303(\mathrm{C}-\mathrm{N}), 1264(\mathrm{C}-\mathrm{O}) \mathrm{cm}^{-1} ;{ }^{1} \mathrm{H}$ NMR (DMSO-d 6$) \delta$ $1.77\left(3 \mathrm{H}, \mathrm{d}, J=7.2 \mathrm{~Hz}, \mathrm{CH}_{3}-\mathrm{CH}-\right), 3.84\left(3 \mathrm{H}, \mathrm{s}, \mathrm{OCH}_{3}\right), 4.25(1 \mathrm{H}, \mathrm{d}$, $\left.J=16 \mathrm{~Hz},-\mathrm{S}-\mathrm{CH}_{2}\right), 4.39\left(1 \mathrm{H}, \mathrm{d}, J=15.6 \mathrm{~Hz},-\mathrm{S}-\mathrm{CH}_{2}\right), 4.70(1 \mathrm{H}, \mathrm{q}$, $\left.J=7.2 \mathrm{~Hz}, \mathrm{CH}_{3}-\mathrm{CH}-\right), 7.13(1 \mathrm{H}, \mathrm{dd}, J=8.8,2.8 \mathrm{~Hz}$, arom.H), 7.26 $(1 \mathrm{H}, \mathrm{s}, \operatorname{arom} . \mathrm{H}), 7.45(1 \mathrm{H}, \mathrm{dd}, J=8.4,1.6 \mathrm{~Hz}$, arom.H), $7.61(2 \mathrm{H}, \mathrm{d}$, $\left.J=8.4 \mathrm{~Hz}, \mathrm{H}-2^{\prime}, \mathrm{H}-6^{\prime}\right)$ 7.75-7.81 (3H, m, arom.H), $7.93(2 \mathrm{H}, \mathrm{d}$, $\left.J=8.8 \mathrm{~Hz}, \mathrm{H}-3^{\prime}, \mathrm{H}-5^{\prime}\right)$; MS (ESI+) $\mathrm{m} / z$ calcd for $\mathrm{C}_{23} \mathrm{H}_{20} \mathrm{ClN}_{4} \mathrm{OS}(\mathrm{M}$ $+\mathrm{H})^{+}$435.11, found 435.15; Anal. Calcd for $\mathrm{C}_{23} \mathrm{H}_{19} \mathrm{ClN}_{4} \mathrm{OS}$ : $\mathrm{C}$ $63.51 ; \mathrm{H}, 4.40 ; \mathrm{N}, 12.88 ; \mathrm{S}, 7.37$. Found: $\mathrm{C}, 63.57 ; \mathrm{H}, 4.49 ; \mathrm{N}$, 12.99; S, 7.14.

4.1.2.14. 3-[1-(6-Methoxynaphtalen-2-yl)ethyl]-6-(2,4-dichlorophenyl)-7H-1,2,4-triazolo[3,4-b]-1,3,4-thiadiazine (2d). Yield $0.30 \mathrm{~g}, 64 \%\left(0.28 \mathrm{~g}, 59 \%\right.$ for MW). Mp: $178-179{ }^{\circ} \mathrm{C}$. IR: $v_{\max }: 1608$ $(\mathrm{C}=\mathrm{N}), 1315(\mathrm{C}-\mathrm{N}), 1266(\mathrm{C}-\mathrm{O}) \mathrm{cm}^{-1} ;{ }^{1} \mathrm{H} \mathrm{NMR}\left(\mathrm{CDCl}_{3}\right) \delta 1.89$ $\left(3 \mathrm{H}, \mathrm{d}, J=7.2 \mathrm{~Hz}, \mathrm{CH}_{3}-\mathrm{CH}-\right), 3.66\left(1 \mathrm{H}, \mathrm{d}, J=15.6 \mathrm{~Hz},-\mathrm{S}_{-} \mathrm{CH}_{2}\right), 3.82$ $\left(1 \mathrm{H}, \mathrm{d}, J=15.2 \mathrm{~Hz},-\mathrm{S}-\mathrm{CH}_{2}\right), 3.91\left(3 \mathrm{H}, \mathrm{s}, \mathrm{OCH}_{3}\right), 4.59(1 \mathrm{H}, \mathrm{q}$, $\left.J=7.6 \mathrm{~Hz}, \mathrm{CH}_{3}-\mathrm{CH}-\right), 7.06(1 \mathrm{H}, \mathrm{d}, J=8.0 \mathrm{~Hz}$, arom. $\mathrm{H}), 7.10(1 \mathrm{H}, \mathrm{d}$, $J=2.4 \mathrm{~Hz}$, arom. H), $7.15(1 \mathrm{H}$, dd, $J=8.8,2.4 \mathrm{~Hz}$, arom. H), 7.26 $(1 \mathrm{H}, \mathrm{dd}, J=8.0,2.0 \mathrm{~Hz}$, arom. $\mathrm{H}), 7.41(1 \mathrm{H}, \mathrm{dd}, J=9.2,2.0 \mathrm{~Hz}$, arom. $\mathrm{H}), 7.48(1 \mathrm{H}, \mathrm{d}, J=2.4 \mathrm{~Hz}$, arom. H), 7.66-7.69 (3H, m, arom. H-3', H$5^{\prime}$ ); MS (ESI+) $m / z$ calcd for $\mathrm{C}_{23} \mathrm{H}_{19} \mathrm{Cl}_{2} \mathrm{~N}_{4} \mathrm{OS}(\mathrm{M}+\mathrm{H})^{+} 469.07$, found 469.11; Anal. Calcd for $\mathrm{C}_{23} \mathrm{H}_{18} \mathrm{Cl}_{2} \mathrm{~N}_{4} \mathrm{OS}$ : C, 58.85; H, 3.87; N, 11.94; S, 6.83. Found: C, 58.75; H, 3.87; N, 11.88; S, 6.73.

4.1.2.15. 3-[1-(6-Methoxynaphtalen-2-yl)ethyl]-6-(4-bromophenyl)-7H-1,2,4-triazolo[3,4-b]-1,3,4-thiadiazine (2e). Yield $0.05 \mathrm{~g}, 11 \%\left(0.19 \mathrm{~g}, 41 \%\right.$ for MW). Mp: $166-168{ }^{\circ} \mathrm{C}$. IR: $v_{\max }: 1607$ $(\mathrm{C}=\mathrm{N}), 1319(\mathrm{C}-\mathrm{N}), 1264(\mathrm{C}-\mathrm{O}) \mathrm{cm}^{-1} ;{ }^{1} \mathrm{H}$ NMR (DMSO-d $\left.{ }_{6}\right) \delta$ $1.76\left(3 \mathrm{H}, \mathrm{d}, J=7.2 \mathrm{~Hz}, \mathrm{CH}_{3}-\mathrm{CH}-\right), 3.84\left(3 \mathrm{H}, \mathrm{s}, \mathrm{OCH}_{3}\right), 4.25(1 \mathrm{H}, \mathrm{d}$, $\left.J=16.0 \mathrm{~Hz},-\mathrm{S}-\mathrm{CH}_{2}\right), 4.38\left(1 \mathrm{H}, \mathrm{d}, J=15.6 \mathrm{~Hz},-\mathrm{S}-\mathrm{CH}_{2}\right), 4.70(1 \mathrm{H}, \mathrm{q}$, $\left.J=6.8 \mathrm{~Hz}, \mathrm{CH}_{3}-\mathrm{CH}-\right), 7.13(1 \mathrm{H}$, dd, $J=9.2,2.8 \mathrm{~Hz}$, arom. $\mathrm{H}), 7.26$ $(1 \mathrm{H}, \mathrm{s}$, arom. $\mathrm{H}), 7.45(1 \mathrm{H}, \mathrm{dd}, J=8.0,2.0 \mathrm{~Hz}$, arom. $\mathrm{H}), 7.73-7.86$ $(7 \mathrm{H}, \mathrm{m}$, arom. $\mathrm{H})$; MS (ESI+) $\mathrm{m} / z$ calcd for $\mathrm{C}_{23} \mathrm{H}_{20} \mathrm{BrN}_{4} \mathrm{OS}(\mathrm{M}+\mathrm{H})^{+}$ 479.05, found 479.11; Anal. Calcd for $\mathrm{C}_{23} \mathrm{H}_{19} \mathrm{BrN}_{4} \mathrm{OS}$ : C, 57.63; $\mathrm{H}$, 3.99; N, 11.69; S, 6.69. Found: C, 57.64; H, 4.20; N, 11.55; S, 6.50.

4.1.2.16. 3-[1-(6-Methoxynaphtalen-2-yl)ethyl]-6-(4-nitrophenyl)7H-1,2,4-triazolo[3,4-b]-1,3,4-thiadiazine (2f). Yield $0.11 \mathrm{~g}$, $24 \%\left(0.28 \mathrm{~g}, 60 \%\right.$ for MW). Mp: $108-110{ }^{\circ} \mathrm{C}$. IR: $v_{\max }: 1605(\mathrm{C}=\mathrm{N})$, $1314(\mathrm{C}-\mathrm{N}), 1265(\mathrm{C}-\mathrm{O}) \mathrm{cm}^{-1} ;{ }^{1} \mathrm{H}$ NMR $\left(\mathrm{CDCl}_{3}\right) \delta 1.92(3 \mathrm{H}, \mathrm{d}$, $\left.J=7.2 \mathrm{~Hz}, \mathrm{CH}_{3}-\mathrm{CH}-\right), 3.79\left(1 \mathrm{H}, \mathrm{d}, J=15.6 \mathrm{~Hz},-\mathrm{S}_{-} \mathrm{CH}_{2}\right), 3.89(3 \mathrm{H}, \mathrm{s}$, $\left.\mathrm{OCH}_{3}\right), 3.94\left(1 \mathrm{H}, \mathrm{d}, J=16.0 \mathrm{~Hz},-\mathrm{S}-\mathrm{CH}_{2}\right), 4.65(1 \mathrm{H}, \mathrm{q}, J=7.2 \mathrm{~Hz}$, $\left.\mathrm{CH}_{3}-\mathrm{CH}-\right), 7.08-7.15(2 \mathrm{H}, \mathrm{m}$, arom. $\mathrm{H}), 7.44(1 \mathrm{H}, \mathrm{dd}, J=8.4,2.0 \mathrm{~Hz}$, arom. $\mathrm{H}), 7.67(3 \mathrm{H}, \mathrm{t}, J=7.2 \mathrm{~Hz}$, arom. $\mathrm{H}), 7.86(2 \mathrm{H}, \mathrm{d}, J=8.8 \mathrm{~Hz}$, arom. H2', H-6'), 8.29 (2H, d, J = 9.2 Hz, arom. H-3', H-5'); MS (ESI +) $\mathrm{m} / z$ calcd for $\mathrm{C}_{23} \mathrm{H}_{20} \mathrm{~N}_{5} \mathrm{O}_{3} \mathrm{~S}(\mathrm{M}+\mathrm{H})^{+} 446.13$, found 446.17; Anal. Calcd for $\mathrm{C}_{23} \mathrm{H}_{19} \mathrm{~N}_{5} \mathrm{O}_{3} \mathrm{~S}$ : C, $62.01 ; \mathrm{H}, 4.30 ; \mathrm{N}, 15.72 ; \mathrm{S}, 7.20$. Found: C, 62.07; H, 4.34; N, 15.69; S, 7.03.

4.1.2.17. 3-[1-(6-Methoxynaphtalen-2-yl)ethyl]-6-(4-methylphenyl)-7H-1,2,4-triazolo[3,4-b]-1,3,4-thiadiazine (2g). Yield $0.11 \mathrm{~g}, 26 \%$ (0.20 g, 48\% for MW). Mp: $169-171{ }^{\circ} \mathrm{C}$. IR: $v_{\max }: 1605$ $(\mathrm{C}=\mathrm{N}), 1309(\mathrm{C}-\mathrm{N}), 1263(\mathrm{C}-\mathrm{O}) \mathrm{cm}^{-1}$; ${ }^{1} \mathrm{H}$ NMR $\left(\mathrm{CDCl}_{3}\right) \delta 1.91$ $\left(3 \mathrm{H}, \mathrm{d}, J=7.6 \mathrm{~Hz}, \mathrm{CH}_{3}-\mathrm{CH}-\right), 2.42\left(3 \mathrm{H}, \mathrm{s},-\mathrm{CH}_{3}\right), 3.71(1 \mathrm{H}, \mathrm{d}$, $\left.J=15.6 \mathrm{~Hz},-\mathrm{S}-\mathrm{CH}_{2}\right), 3.89\left(1 \mathrm{H}, \mathrm{d}, J=15.2 \mathrm{~Hz},-\mathrm{S}-\mathrm{CH}_{2}\right), 3.89(3 \mathrm{H}, \mathrm{s},-$ $\left.\mathrm{OCH}_{3}\right), 4.68\left(1 \mathrm{H}, \mathrm{q}, J=7.6 \mathrm{~Hz}, \mathrm{CH}_{3}-\mathrm{CH}-\right), 7.08-7.13(2 \mathrm{H}, \mathrm{m}$, arom. H), $7.26(2 \mathrm{H}, \mathrm{d}, J=8.4 \mathrm{~Hz}$, arom.H), $7.48(1 \mathrm{H}, \mathrm{dd}, J=8.4,2.0 \mathrm{~Hz}$, arom.H), 7.62-7.74 (5H, m, arom.H); MS (ESI+) m/z calcd for $\mathrm{C}_{24} \mathrm{H}_{23^{-}}$ $\mathrm{N}_{4} \mathrm{OS}(\mathrm{M}+\mathrm{H})^{+}$415.16, found 415.16; Anal. Calcd for $\mathrm{C}_{24} \mathrm{H}_{22} \mathrm{~N}_{4^{-}}$ OS1/4 $\mathrm{H}_{2} \mathrm{O}$ : C, 68.79; H, 5.41; N, 13.37; S, 7.65. Found: C, 68.75; H, $5.23 ; \mathrm{N}, 13.01 ; \mathrm{S}, 7.49$.
4.1.2.18. 3-[1-(6-Methoxynaphtalen-2-yl)ethyl]-6-(4-methoxyphenyl)-7H-1,2,4-triazolo[3,4-b]-1,3,4-thiadiazine (2h). Yield $0.21 \mathrm{~g}, 49 \%$ (0.29 g, 67\% for MW). Mp: $121-122{ }^{\circ} \mathrm{C}$. IR: $v_{\max }: 1606$ $(\mathrm{C}=\mathrm{N}), 1316(\mathrm{C}-\mathrm{N}), 1257(\mathrm{C}-\mathrm{O}) \mathrm{cm}^{-1} ;{ }^{1} \mathrm{H}$ NMR $\left(\mathrm{CDCl}_{3}\right) \delta 1.91(3 \mathrm{H}$, d, $\left.J=7.6 \mathrm{~Hz}, \mathrm{CH}_{3}-\mathrm{CH}-\right), 3.69\left(1 \mathrm{H}, \mathrm{d}, J=15.6 \mathrm{~Hz},-\mathrm{S}-\mathrm{CH}_{2}\right), 3.86(1 \mathrm{H}, \mathrm{d}$, $\left.J=15.6 \mathrm{~Hz},-\mathrm{S}-\mathrm{CH}_{2}\right), 3.88\left(6 \mathrm{H}, \mathrm{s},-\mathrm{OCH}_{3}\right), 4.68\left(1 \mathrm{H}, \mathrm{q}, J=7.2 \mathrm{~Hz}, \mathrm{CH}_{3}-\right.$ $\mathrm{CH}-), 6.95(2 \mathrm{H}, \mathrm{d}, J=8.8 \mathrm{~Hz}$, arom. H), 7.08-7.13 (2H, m, arom. H), $7.47(1 \mathrm{H}, \mathrm{dd}, J=8.0,2.0 \mathrm{~Hz}$, arom. $\mathrm{H}), 7.66-7.73(5 \mathrm{H}, \mathrm{m}$, arom. $\mathrm{H})$; MS (ESI+) $m / z$ calcd for $\mathrm{C}_{24} \mathrm{H}_{23} \mathrm{~N}_{4} \mathrm{O}_{2} \mathrm{~S}(\mathrm{M}+\mathrm{H})^{+} 431.15$, found 431.20; Anal. Calcd for $\mathrm{C}_{24} \mathrm{H}_{22} \mathrm{~N}_{4} \mathrm{O}_{2} \mathrm{~S}$ : C, 66.96; H, 5.15; N, 13.01; S, 7.45. Found: C, 67.03; H, 5.37; N, 12.81; S, 7.33.

4.1.2.19. 3-[1-(6-Methoxynaphtalen-2-yl)ethyl]-6-(4-trifluoro methylphenyl)-7H-1,2,4-triazolo[3,4-b]-1,3,4-thiadiazine (2i). Yield $0.18 \mathrm{~g}, 37 \%\left(0.29 \mathrm{~g}, 59 \%\right.$ for MW). Mp: $149-150{ }^{\circ} \mathrm{C}$. IR: $v_{\max }$ : $1607(\mathrm{C}=\mathrm{N}), 1314(\mathrm{C}-\mathrm{N}), 1269(\mathrm{C}-\mathrm{O}) \mathrm{cm}^{-\mathbf{1}} ;{ }^{1} \mathrm{H} \mathrm{NMR}\left(\mathrm{CDCl}_{\mathbf{3}}\right) \boldsymbol{\delta} 1.78$ $\left(3 \mathrm{H}, \mathrm{d}, \boldsymbol{J}=7.2 \mathrm{~Hz}, \mathrm{CH}_{\mathbf{3}}-\mathrm{CH}-\right), 3.84\left(3 \mathrm{H}, \mathrm{s},-\mathrm{OCH}_{\mathbf{3}}\right), 4.32(1 \mathrm{H}, \mathrm{d}$, $\left.\boldsymbol{J}=15.6 \mathrm{~Hz},-\mathrm{S}-\mathrm{CH}_{\mathbf{2}}\right), 4.44\left(1 \mathrm{H}, \mathrm{d}, \boldsymbol{J}=16.0 \mathrm{~Hz},-\mathrm{S}-\mathrm{CH}_{\mathbf{2}}\right), 4.71(1 \mathrm{H}, \mathrm{q}$, $\left.\boldsymbol{J}=7.6 \mathrm{~Hz}, \mathrm{CH}_{3}-\mathrm{CH}-\right), 7.13(1 \mathrm{H}$, dd, $\boldsymbol{J}=8.8,2.8 \mathrm{~Hz}$, arom. $\mathrm{H}), 7.26$ $(1 \mathrm{H}, \mathrm{d}, \boldsymbol{J}=2.8 \mathrm{~Hz}$, arom. H), $7.46(1 \mathrm{H}, \mathrm{dd}, \boldsymbol{J}=8.4,2.0 \mathrm{~Hz}$, arom. $\mathrm{H})$, 7.76-7.82 (3H, m, arom. H), $7.91(2 \mathrm{H}, \mathrm{d}, \boldsymbol{J}=8.4 \mathrm{~Hz}$, arom. $\mathrm{H}), 8.10$ $(2 \mathrm{H}, \mathrm{d}, \boldsymbol{J}=8.0 \mathrm{~Hz}$, arom. $\mathrm{H})$; MS (ESI+) $\boldsymbol{m} / \boldsymbol{z}$ calcd for $\mathrm{C}_{24} \mathrm{H}_{20} \mathrm{~F}_{3} \mathrm{~N}_{4} \mathrm{OS}$ $(\mathrm{M}+\mathrm{H})^{+} 469.13$, found 469.04; Anal. Calcd for $\mathrm{C}_{24} \mathrm{H}_{19} \mathrm{~F}_{3} \mathrm{~N}_{4} \mathrm{OS}$ : C, 61.53; H, 4.09; N, 11.96; S, 6.84. Found: C, 61.76; H, 4.28; N, 11.82; S, 6.67.

4.1.2.20. 3-[1-(6-Methoxynaphtalen-2-yl)ethyl]-6-(4-trifluoromethoxyphenyl)-7H-1,2,4-triazolo[3,4-b]-1,3,4-thiadiazine (2j). Yield $0.19 \mathrm{~g}, 39 \%$ (0.35 g, $72 \%$ for MW). Mp: $139-140{ }^{\circ} \mathrm{C}$. IR: $v_{\max }$ : $1606(\mathrm{C}=\mathrm{N}), 1322(\mathrm{C}-\mathrm{N}), 1255(\mathrm{C}-\mathrm{O}) \mathrm{cm}^{-\mathbf{1}} ;{ }^{1} \mathrm{H} \mathrm{NMR}\left(\mathrm{CDCl}_{\mathbf{3}}\right) \boldsymbol{\delta} 1.91$ $\left(3 \mathrm{H}, \mathrm{d}, \boldsymbol{J}=7.2 \mathrm{~Hz}, \mathrm{CH}_{\mathbf{3}}-\mathrm{CH}-\right), 3.73\left(1 \mathrm{H}, \mathrm{d}, \boldsymbol{J}=15.6 \mathrm{~Hz},-\mathrm{S}-\mathrm{CH}_{\mathbf{2}}\right), 3.89$ $\left(1 \mathrm{H}, \mathrm{d}, \boldsymbol{J}=15.2 \mathrm{~Hz},-\mathrm{S}-\mathrm{CH}_{2}\right), 3.89\left(3 \mathrm{H}, \mathrm{s},-\mathrm{OCH}_{\mathbf{3}}\right), 4.66(1 \mathrm{H}, \mathrm{q}$, $\left.\boldsymbol{J}=7.2 \mathrm{~Hz}, \mathrm{CH}_{3}-\mathrm{CH}-\right), 7.08-7.14(2 \mathrm{H}, \mathrm{m}, \operatorname{arom} . \mathrm{H}), 7.29(2 \mathrm{H}, \mathrm{d}$, $\boldsymbol{J}=8.0 \mathrm{~Hz}$, arom.H), $7.45(1 \mathrm{H}, \mathrm{dd}, \boldsymbol{J}=8.0,2.0 \mathrm{~Hz}$, arom. $\mathrm{H}), 7.65-7.76$ $\left(5 \mathrm{H}, \mathrm{m}\right.$, arom.H); MS (ESI+) $\boldsymbol{m} / \boldsymbol{z}$ calcd for $\mathrm{C}_{24} \mathrm{H}_{20} \mathrm{~F}_{3} \mathrm{~N}_{4} \mathrm{O}_{2} \mathrm{~S}(\mathrm{M}+\mathrm{H})^{+}$ 485.13, found 485.12; Anal. Calcd for $\mathrm{C}_{24} \mathrm{H}_{19} \mathrm{~F}_{3} \mathrm{~N}_{4} \mathrm{O}_{2} \mathrm{~S}$ : C, 59.50; $\mathrm{H}$, 3.95; N, 11.56; S, 6.62. Found: C, 59.56; H, 4.16; N, 11.63; S, 6.53.

4.1.2.21. 3-[1-(2-Fluoro-1,1'-biphenyl-4-yl)ethyl]-6-phenyl-7H1,2,4-triazolo[3,4-b]-1,3,4-thiadiazine (3a). Yield $0.15 \mathrm{~g}$, $36 \%(0.24 \mathrm{~g}, 57 \%$ for $\mathrm{MW})$. Mp: $131-133^{\circ} \mathrm{C}$. IR: $v_{\max }: 1583(\mathrm{C}=\mathrm{N})$, $1319(\mathrm{C}-\mathrm{N}) \mathrm{cm}^{-1} ;{ }^{1} \mathrm{H}$ NMR $\left(\mathrm{CDCl}_{3}\right) \delta 1.88\left(3 \mathrm{H}, \mathrm{d}, \mathrm{J}=7.6 \mathrm{~Hz}, \mathrm{CH}_{3^{-}}\right.$ $\mathrm{CH}-), 3.85\left(1 \mathrm{H}, \mathrm{d}, J=15.6 \mathrm{~Hz},-\mathrm{S}_{-} \mathrm{CH}_{2}\right), 3.97(1 \mathrm{H}, \mathrm{d}, J=15.2 \mathrm{~Hz},-$ $\left.\mathrm{S}-\mathrm{CH}_{2}\right), 4.59\left(1 \mathrm{H}, \mathrm{q}, \mathrm{J}=6.8 \mathrm{~Hz}, \mathrm{CH}_{3}-\mathrm{CH}-\right), 7.18-7.24(2 \mathrm{H}, \mathrm{m}$, arom. $\mathrm{H})$, 7.34-7.56 (9H, m, arom. H), 7.78-7.80 (2H, m, arom. H); MS (ESI+) $\mathrm{m} / z$ calcd for $\mathrm{C}_{24} \mathrm{H}_{20} \mathrm{FN}_{4} \mathrm{~S}(\mathrm{M}+\mathrm{H})^{+} 415.14$, found 415.17; Anal. Calcd for $\mathrm{C}_{24} \mathrm{H}_{19} \mathrm{FN}_{4} \mathrm{~S}$ : C, 69.54; $\mathrm{H}, 4.62 ; \mathrm{N}, 13.52 ; \mathrm{S}, 7.74$. Found: $\mathrm{C}$, 69.22; H, 4.52; N, 13.77; S, 7.70.

4.1.2.22. 3-[1-(2-Fluoro-1,1'-biphenyl-4-yl)ethyl]-6-(4-fluorophenyl)-7H-1,2,4-triazolo[3,4-b]-1,3,4-thiadiazine (3b). Yield $0.32 \mathrm{~g}, 74 \%\left(0.28 \mathrm{~g}, 63 \%\right.$ for MW). Mp: $175-176^{\circ} \mathrm{C}$. IR: $v_{\max }: 1600$ $(\mathrm{C}=\mathrm{N}), 1318(\mathrm{C}-\mathrm{N}) \mathrm{cm}^{-\mathbf{1}} ;{ }^{1} \mathrm{H}$ NMR $\left(\mathrm{CDCl}_{\mathbf{3}}\right) \boldsymbol{\delta} 1.87(3 \mathrm{H}, \mathrm{d}, \boldsymbol{J}=7.6 \mathrm{~Hz}$, $\left.\mathrm{CH}_{\mathbf{3}}-\mathrm{CH}-\right), 3.83\left(1 \mathrm{H}, \mathrm{d}, \boldsymbol{J}=15.6 \mathrm{~Hz},-\mathrm{S}-\mathrm{CH}_{2}\right), 3.94(1 \mathrm{H}, \mathrm{d}, \boldsymbol{J}=15.6 \mathrm{~Hz}$, $\left.-\mathrm{S}-\mathrm{CH}_{2}\right), 4.57\left(1 \mathrm{H}, \mathrm{q}, \boldsymbol{J}=7.6 \mathrm{~Hz}, \mathrm{CH}_{3}-\mathrm{CH}-\right), 7.16-7.22(4 \mathrm{H}, \mathrm{m}$, arom. H), 7.35-7.51 (6H, m, arom. H), 7.78-7.82 (2H, m, arom. H); MS (ESI+) $\boldsymbol{m} / \boldsymbol{z}$ calcd for $\mathrm{C}_{\mathbf{2 4}} \mathrm{H}_{19} \mathrm{~F}_{2} \mathrm{~N}_{\mathbf{4}} \mathrm{S}(\mathrm{M}+\mathrm{H})^{+} 433.13$, found 433.17; Anal. Calcd for $\mathrm{C}_{24} \mathrm{H}_{18} \mathrm{~F}_{2} \mathrm{~N}_{4} \mathrm{~S}: \mathrm{C}, 66.65 ; \mathrm{H}, 4.20 ; \mathrm{N}, 12.95 ; \mathrm{S}, 7.41$. Found: C, 66.66; H, 4.06; N, 12.98; S, 7.30.

4.1.2.23. 3-[1-(2-Fluoro-1,1'-biphenyl-4-yl)ethyl]-6-(4-chlorophenyl)-7H-1,2,4-triazolo[3,4-b]-1,3,4-thiadiazine (3c). Yield $0.41 \mathrm{~g}, 90 \%$ (0.29 g, $63 \%$ for MW). Mp: $199-200{ }^{\circ} \mathrm{C}$. IR: $v_{\max }: 1591$ $(\mathrm{C}=\mathrm{N}), 1321(\mathrm{C}-\mathrm{N}) \mathrm{cm}^{-1} ;{ }^{1} \mathrm{H}$ NMR $\left(\mathrm{CDCl}_{3}\right) \delta 1.86(3 \mathrm{H}, \mathrm{d}$, $\left.J=7.2 \mathrm{~Hz}, \mathrm{CH}_{3}-\mathrm{CH}-\right), 3.82\left(1 \mathrm{H}, \mathrm{d}, J=15.6 \mathrm{~Hz},-\mathrm{S}-\mathrm{CH}_{2}\right), 3.93(1 \mathrm{H}, \mathrm{d}$, $\left.J=15.6 \mathrm{~Hz},-\mathrm{S}-\mathrm{CH}_{2}\right), 4.56\left(1 \mathrm{H}, \mathrm{q}, J=7.6 \mathrm{~Hz}, \mathrm{CH}_{3}-\mathrm{CH}-\right), 7.15-7.21$ 
$(2 \mathrm{H}, \mathrm{m}$, arom. $\mathrm{H}), 7.34-7.51(8 \mathrm{H}, \mathrm{m}$, arom. $\mathrm{H}), 7.72(2 \mathrm{H}, \mathrm{d}, J=8.8 \mathrm{~Hz}$ arom. H); MS (ESI+) $m / z$ calcd for $\mathrm{C}_{24} \mathrm{H}_{19} \mathrm{FClN}_{4} \mathrm{~S}(\mathrm{M}+\mathrm{H})^{+} 449.10$, found 449.15; Anal. Calcd for $\mathrm{C}_{24} \mathrm{H}_{18} \mathrm{FClN}_{4} \mathrm{~S}$ : C, 64.21; $\mathrm{H}, 4.04 ; \mathrm{N}$, 12.48; S, 7.14. Found: C, 64.23; H, 3.92; N, 12.57; S, 7.05.

4.1.2.24. 3-[1-(2-Fluoro-1,1'-biphenyl-4-yl)ethyl]-6-(2,4-dichlorophenyl)-7H-1,2,4-triazolo[3,4-b]-1,3,4-thiadiazine (3d). Yield $0.38 \mathrm{~g}, 79 \%\left(0.24 \mathrm{~g}, 50 \%\right.$ for MW). Mp: $182-183{ }^{\circ} \mathrm{C}$. IR: $v_{\max }: 1583$ $(\mathrm{C}=\mathrm{N}), 1303(\mathrm{C}-\mathrm{N}) \mathrm{cm}^{-\mathbf{1}} ;{ }^{1} \mathrm{H}$ NMR $\left(\mathrm{CDCl}_{\mathbf{3}}\right) \boldsymbol{\delta} 1.85(3 \mathrm{H}, \mathrm{d}, \boldsymbol{J}=6.8 \mathrm{~Hz}$, $\left.\mathrm{CH}_{\mathbf{3}}-\mathrm{CH}-\right), 3.79\left(1 \mathrm{H}, \mathrm{d}, \boldsymbol{J}=15.6 \mathrm{~Hz},-\mathrm{S}-\mathrm{CH}_{2}\right), 3.88(1 \mathrm{H}, \mathrm{d}, \boldsymbol{J}=15.6 \mathrm{~Hz}$, $\left.-\mathrm{S}-\mathrm{CH}_{2}\right), 4.51\left(1 \mathrm{H}, \mathrm{q}, \boldsymbol{J}=6.8 \mathrm{~Hz}, \mathrm{CH}_{3}-\mathrm{CH}-\right), 7.13-7.19(2 \mathrm{H}, \mathrm{m}$, arom. $\mathrm{H}), 7.28-7.46$ (6H, m, arom. H), 7.51-7.53 (3H, m, arom. H-3', H-5', H-6'); MS (ESI+) $\boldsymbol{m} / \boldsymbol{z}$ calcd for $\mathrm{C}_{24} \mathrm{H}_{18} \mathrm{FCl}_{2} \mathrm{~N}_{4} \mathrm{~S}(\mathrm{M}+\mathrm{H})^{+} 483.06$, found 483.10; Anal. Calcd for $\mathrm{C}_{24} \mathrm{H}_{17} \mathrm{FCl}_{2} \mathrm{~N}_{4} \mathrm{~S}$ : C, 59.63; $\mathrm{H}, 3.54 ; \mathrm{N}, 11.59$; S, 6.63. Found: C, 59.84; H, 3.43; N, 11.92; S, 6.71 .

4.1.2.25. 3-[1-(2-Fluoro-1,1'-biphenyl-4-yl)ethyl]-6-(4-bromophenyl)-7H-1,2,4-triazolo[3,4-b]-1,3,4-thiadiazine (3e). Yield $0.34 \mathrm{~g}, 68 \%$ (0.30 g, $60 \%$ for MW). Mp: $196-197{ }^{\circ} \mathrm{C}$. IR: $v_{\max }: 1585$ $(\mathrm{C}=\mathrm{N}), 1322(\mathrm{C}-\mathrm{N}) \mathrm{cm}^{-\mathbf{1}} ;{ }^{1} \mathrm{H}$ NMR $\left(\mathrm{CDCl}_{\mathbf{3}}\right) \boldsymbol{\delta} 1.87(3 \mathrm{H}, \mathrm{d}, \boldsymbol{J}=7.2 \mathrm{~Hz}$, $\left.\mathrm{CH}_{3}-\mathrm{CH}-\right), 3.83\left(1 \mathrm{H}, \mathrm{d}, \boldsymbol{J}=15.6 \mathrm{~Hz},-\mathrm{S}-\mathrm{CH}_{2}\right), 3.94(1 \mathrm{H}, \mathrm{d}, \boldsymbol{J}=15.2 \mathrm{~Hz}$, $\left.-\mathrm{S}-\mathrm{CH}_{2}\right), 4.57\left(1 \mathrm{H}, \mathrm{q}, \boldsymbol{J}=7.6 \mathrm{~Hz}, \mathrm{CH}_{3}-\mathrm{CH}-\right), 7.15-7.22(2 \mathrm{H}, \mathrm{m}$, arom. $\mathrm{H}), 7.35-7.52$ (6H, m, arom. H), 7.65 (4H, s, arom. H-2', H-3', H-5', $\left.\mathrm{H}-6^{\prime}\right)$; MS (ESI+) $\boldsymbol{m} / \boldsymbol{z}$ calcd for $\mathrm{C}_{24} \mathrm{H}_{19} \mathrm{FBrN}_{4} \mathrm{~S}(\mathrm{M}+\mathrm{H})^{+} 493.05$ found 493.12; Anal. Calcd for $\mathrm{C}_{24} \mathrm{H}_{18} \mathrm{FBrN}_{\mathbf{4}} \mathrm{S}$ : C, 58.42; H, 3.68; N, 11.36; S, 6.50. Found: C, 58.28; H, 3.70; N, 11.34; S, 6.46.

4.1.2.26. 3-[1-(2-Fluoro-1,1'-biphenyl-4-yl)ethyl]-6-(4-nitrophenyl)-7H-1,2,4-triazolo[3,4-b]-1,3,4-thiadiazine (3f). Yield $0.26 \mathrm{~g}, 56 \%$ (0.19 g, $41 \%$ for MW). Mp: $174-176{ }^{\circ} \mathrm{C}$. IR: $v_{\max }: 1582$ $(\mathrm{C}=\mathrm{N}), 1322(\mathrm{C}-\mathrm{N}) \mathrm{cm}^{-1} ;{ }^{1} \mathrm{H}$ NMR $\left(\mathrm{CDCl}_{3}\right) \delta 1.88(3 \mathrm{H}, \mathrm{d}, J=6.8 \mathrm{~Hz}$, $\left.\mathrm{CH}_{3}-\mathrm{CH}-\right), 3.91\left(1 \mathrm{H}, \mathrm{d}, J=15.6 \mathrm{~Hz},-\mathrm{S}-\mathrm{CH}_{2}\right), 4.01(1 \mathrm{H}, \mathrm{d}, J=15.6 \mathrm{~Hz}$, $\left.-\mathrm{S}-\mathrm{CH}_{2}\right), 4.57\left(1 \mathrm{H}, \mathrm{q}, \mathrm{J}=7.6 \mathrm{~Hz}, \mathrm{CH}_{3}-\mathrm{CH}-\right), 7.14-7.21(2 \mathrm{H}, \mathrm{m}$, arom. $\mathrm{H}), 7.35-7.51\left(6 \mathrm{H}, \mathrm{m}\right.$, arom. H), $7.96\left(2 \mathrm{H}, \mathrm{d}, J=9.2 \mathrm{~Hz}\right.$, arom. $\mathrm{H}-2^{\prime}$,

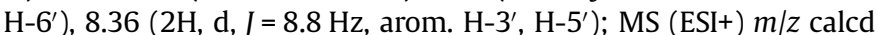
for $\mathrm{C}_{24} \mathrm{H}_{19} \mathrm{FN}_{5} \mathrm{O}_{2} \mathrm{~S}(\mathrm{M}+\mathrm{H})^{+} 460.12$ found 460.18; Anal. Calcd for $\mathrm{C}_{24^{-}}$ $\mathrm{H}_{18} \mathrm{FN}_{5} \mathrm{O}_{2} \mathrm{~S}$ : C, 62.73; H, 3.95; N, 15.24; S, 6.98. Found: C, 62.90; H, 3.87; N, 15.42; S, 7.11.

4.1.2.27. 3-[1-(2-Fluoro-1,1'-biphenyl-4-yl)ethyl]-6-(4-methylphenyl)-7H-1,2,4-triazolo[3,4-b]-1,3,4-thiadiazine (3g). Yield $0.15 \mathrm{~g}, 34 \%$ (0.15 g, 35\% for MW). Mp: $150-151{ }^{\circ} \mathrm{C}$. IR: $v_{\max }: 1595$ $(\mathrm{C}=\mathrm{N}), 1320(\mathrm{C}-\mathrm{N}) \mathrm{cm}^{-1} ;{ }^{1} \mathrm{H}$ NMR $\left(\mathrm{CDCl}_{3}\right) \delta 1.87(3 \mathrm{H}, \mathrm{d}, J=7.6 \mathrm{~Hz}$, $\left.\mathrm{CH}_{3}-\mathrm{CH}-\right), 2.44\left(3 \mathrm{H}, \mathrm{s},-\mathrm{CH}_{3}\right), 3.82\left(1 \mathrm{H}, \mathrm{d}, J=15.2 \mathrm{~Hz},-\mathrm{S}-\mathrm{CH}_{2}\right), 3.95$ $\left(1 \mathrm{H}, \mathrm{d}, J=15.6 \mathrm{~Hz},-\mathrm{S}-\mathrm{CH}_{2}\right), 4.59\left(1 \mathrm{H}, \mathrm{q}, J=7.2 \mathrm{~Hz}, \mathrm{CH}_{3}-\mathrm{CH}-\right), 7.18-$ $7.24(2 \mathrm{H}, \mathrm{m}$, arom. H), 7.30-7.51 $(8 \mathrm{H}, \mathrm{m}$, arom. $\mathrm{H}), 7.69(2 \mathrm{H}, \mathrm{d}$, $J=8.4 \mathrm{~Hz}$, arom. $\mathrm{H})$; MS (ESI+) $\mathrm{m} / z$ calcd for $\mathrm{C}_{25} \mathrm{H}_{22} \mathrm{FN}_{4} \mathrm{~S}(\mathrm{M}+\mathrm{H})^{+}$ 429.16 found 429.17; Anal. Calcd for $\mathrm{C}_{25} \mathrm{H}_{21} \mathrm{FN}_{4} \mathrm{~S} .1 / 4 \mathrm{H}_{2} \mathrm{O}$ : C, 69.34; H, 5.00; N, 12.94; S, 7.40. Found: C, 69.16; H, 4.97; N, 12.83; S, 7.50 .

4.1.2.28. 3-[1-(2-Fluoro-1,1'-biphenyl-4-yl)ethyl]-6-(4-methoxyphenyl)-7H-1,2,4-triazolo[3,4-b]-1,3,4-thiadiazine (3h). $\quad$ Yield $0.19 \mathrm{~g}, 42 \%\left(0.24 \mathrm{~g}, 54 \%\right.$ for MW). Mp: $240-241^{\circ} \mathrm{C}$. IR: $v_{\max }: 1594$ $(\mathrm{C}=\mathrm{N}), 1320(\mathrm{C}-\mathrm{N}), 1258(\mathrm{C}-\mathrm{O}) \mathrm{cm}^{-1} ;{ }^{1} \mathrm{H}$ NMR $\left(\mathrm{CDCl}_{3}\right) \delta 1.92$ $\left(3 \mathrm{H}, \mathrm{d}, J=6.8 \mathrm{~Hz}, \mathrm{CH}_{3}-\mathrm{CH}-\right), 3.89\left(3 \mathrm{H}, \mathrm{s},-\mathrm{OCH}_{3}\right), 4.14(1 \mathrm{H}, \mathrm{d}$, $\left.J=15.2 \mathrm{~Hz},-\mathrm{S}-\mathrm{CH}_{2}\right), 4.41\left(1 \mathrm{H}, \mathrm{d}, J=15.6 \mathrm{~Hz},-\mathrm{S}-\mathrm{CH}_{2}\right), 4.72(1 \mathrm{H}, \mathrm{q}$, $\left.J=7.6 \mathrm{~Hz}, \mathrm{CH}_{3}-\mathrm{CH}-\right), 7.01\left(2 \mathrm{H}, \mathrm{d}, J=8.4 \mathrm{~Hz}\right.$, arom. $\left.\mathrm{H}^{-} 3^{\prime}, \mathrm{H}-5^{\prime}\right), 7.20-$ $7.51(8 \mathrm{H}, \mathrm{m}$, arom. $\mathrm{H}), 7.86(2 \mathrm{H}, \mathrm{d}, J=8.4 \mathrm{~Hz}$, arom. H); MS (ESI+) $\mathrm{m} / z$ calcd for $\mathrm{C}_{25} \mathrm{H}_{22} \mathrm{FN}_{4} \mathrm{OS}(\mathrm{M}+\mathrm{H})^{+} 445.15$ found 445.20 ; Anal. Calcd for $\mathrm{C}_{25} \mathrm{H}_{21} \mathrm{FN}_{4} \mathrm{OS}$ : C, 67.55; $\mathrm{H}, 4.76 ; \mathrm{N}, 12.60 ; \mathrm{S}, 7.21$. Found: C, 67.55; $\mathrm{H}, 4.65$; N, 12.50; S, 6.97.

4.1.2.29. 3-[1-(2-Fluoro-1,1'-biphenyl-4-yl)ethyl]-6-(4-trifluoromethylphenyl)-7H-1,2,4-triazolo[3,4-b]-1,3,4-thiadiazine (3i). Yield $0.16 \mathrm{~g}, 32 \%\left(0.35 \mathrm{~g}, 70 \%\right.$ for MW). Mp: $166-167{ }^{\circ} \mathrm{C}$. IR: $v_{\max }$ : $1583(\mathrm{C}=\mathrm{N}), 1316(\mathrm{C}-\mathrm{N}) \mathrm{cm}^{-\mathbf{1}} ;{ }^{\mathbf{1}} \mathrm{H}$ NMR $\left(\mathrm{CDCl}_{\mathbf{3}}\right) \boldsymbol{\delta} 2.42(3 \mathrm{H}, \mathrm{d}$,
$\left.\boldsymbol{J}=7.6 \mathrm{~Hz}, \mathrm{CH}_{\mathbf{3}}-\mathrm{CH}-\right), 4.42\left(1 \mathrm{H}, \mathrm{d}, \boldsymbol{J}=15.6 \mathrm{~Hz},-\mathrm{S}-\mathrm{CH}_{2}\right), 4.53(1 \mathrm{H}, \mathrm{d}$, $\left.\boldsymbol{J}=15.6 \mathrm{~Hz},-\mathrm{S}-\mathrm{CH}_{2}\right), 5.11\left(1 \mathrm{H}, \mathrm{q}, \boldsymbol{J}=7.2 \mathrm{~Hz}, \mathrm{CH}_{\mathbf{3}}-\mathrm{CH}-\right), 7.69-7.75$ $(2 \mathrm{H}, \mathrm{m}$, arom. H), 7.88-8.04 (6H, m, arom. H), $8.30(2 \mathrm{H}, \mathrm{d}, \boldsymbol{J}=8.8 \mathrm{~Hz}$, arom. H-2', H-6'), 8.44 (2H, d, $\boldsymbol{J}=8.0 \mathrm{~Hz}$, arom. H-3', H-5'); MS (ESI $+) \boldsymbol{m} / \boldsymbol{z}$ calcd for $\mathrm{C}_{25} \mathrm{H}_{19} \mathrm{~F}_{4} \mathrm{~N}_{4} \mathrm{~S}(\mathrm{M}+\mathrm{H})^{+} 483.13$ found 483.04; Anal. Calcd for $\mathrm{C}_{25} \mathrm{H}_{18} \mathrm{~F}_{4} \mathrm{~N}_{4} \mathrm{~S}$ : C, 62.23; H, 3.76; N, 11.61; S, 6.64. Found: C, 62.23; H, 3.80; N, 11.67; S, 6.73.

4.1.2.30. 3-[1-(2-Fluoro-1,1'-biphenyl-4-yl)ethyl]-6-(4-trifluoromethoxyphenyl)-7H-1,2,4-triazolo [3,4-b]-1,3,4-thiadiazine (3j). Yield $0.20 \mathrm{~g}, 39 \%(0.18 \mathrm{~g}, 35 \%$ for $\mathrm{MW})$. Mp: 170 $171{ }^{\circ} \mathrm{C}$. IR: $v_{\max }: 1597(\mathrm{C}=\mathrm{N}), 1317(\mathrm{C}-\mathrm{N}), 1294(\mathrm{C}-\mathrm{O}) \mathrm{cm}^{-1} ;{ }^{1} \mathrm{H}$ NMR $\left(\mathrm{CDCl}_{3}\right) \delta 1.88\left(3 \mathrm{H}, \mathrm{d}, J=7.2 \mathrm{~Hz}, \mathrm{CH}_{3}-\mathrm{CH}-\right), 3.85(1 \mathrm{H}, \mathrm{d}$, $\left.J=15.6 \mathrm{~Hz},-\mathrm{S}-\mathrm{CH}_{2}\right), 3.96\left(1 \mathrm{H}, \mathrm{d}, J=15.2 \mathrm{~Hz},-\mathrm{S}-\mathrm{CH}_{2}\right), 4.57(1 \mathrm{H}, \mathrm{q}$, $\left.J=7.6 \mathrm{~Hz}, \mathrm{CH}_{3}-\mathrm{CH}-\right), 7.16-7.22(2 \mathrm{H}, \mathrm{m}$, arom. $\mathrm{H}), 7.34-7.44(6 \mathrm{H}$ m, arom. H), $7.50\left(2 \mathrm{H}, \mathrm{d}, J=8.4 \mathrm{~Hz}\right.$, arom. $\left.\mathrm{H}-2^{\prime}, \mathrm{H}-6^{\prime}\right), 7.84(2 \mathrm{H}, \mathrm{d}$,

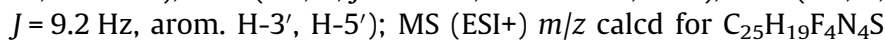
$(\mathrm{M}+\mathrm{H})^{+} 499.12$ found 499.10; Anal. Calcd for $\mathrm{C}_{25} \mathrm{H}_{18} \mathrm{~F}_{4} \mathrm{~N}_{4} \mathrm{OS}$ : $\mathrm{C}$, $60.24 ; \mathrm{H}, 3.64 ; \mathrm{N}, 11.24 ; \mathrm{S}, 6.43$. Found: C, 59.99; H, 3.71; N, $11.08 ; \mathrm{S}, 6.51$

\subsection{Pharmacology}

\subsubsection{Cells and culture}

Human liver (Huh7, HepG2, Hep-3B, Mahlavu, FOCUS and Snu475), breast (MCF7) and colon (HCT116) cancer cell lines were cultured routinely at $37{ }^{\circ} \mathrm{C}$ under $5 \% \mathrm{CO}_{2}$ in Dulbecco's Modified Eagle's Standard (DMEM) medium with 10\% Fetal Bovine Serum (FBS), $0.1 \mathrm{mM}$ nonessential amino acids (NEAA), 100 units/mL penicillin and $100 \mathrm{lg} / \mathrm{mL}$ streptomycin (Gibco, Invitrogen, Carlsbad, CA, USA).

\subsubsection{NCI-60. Sulforhodamine B assay for in vitro cytotoxicity screening}

Human liver cancer (Huh7, HepG2, Hep3B, Mahlavu, FOCUS and Snu475), breast cancer (MCF7) and colon cancer (HCT116) cell lines were inoculated into 96-well plates (1000-3000 cell/well) and grown for $24 \mathrm{~h}$. The cells were then treated with increasing concentrations of the compounds $(2.5-40 \mu \mathrm{M})$ for $72 \mathrm{~h}$. Later, the growth medium was aspirated and samples were washed with 1xPBS ( $\mathrm{CaCl}_{2^{-}}, \mathrm{MgCl}_{2}$-free) (Gibco, Invitrogen, Carlsbad, CA, USA) and fixed with $10 \%(\mathrm{v} / \mathrm{v})$ trichloroacetic acid (Merck, Schuchardt, Germany) by incubation for $1 \mathrm{~h}$ at $4{ }^{\circ} \mathrm{C}$. Samples were then washed five times with deionized water and left to air dry. Finally, $50 \mu \mathrm{l}$ of a $0.4 \%(\mathrm{~m} / \mathrm{v})$ of sulforhodamine (Sigma-Aldrich, St. Louis, USA) in $1 \%$ acetic acid solution was added to each well and the plates were incubated for $10 \mathrm{~min}$ at room temperature. The unbound stain was removed by washing the samples five times with $1 \%$ acetic acid and left to air dry. The bound sulforhodamine B (Sigma-Aldrich) was then solubilized using $10 \mathrm{mM}$ Tris-base (Amresco, USA). The absorbance values were obtained at $515 \mathrm{~nm}$. All experiments were done in triplicate. Data with $R^{2}$ values between 0.8 and 1 was considered significant and standard deviations were included in the related anti-proliferative data tables.

\subsubsection{Real-time cell electronic sensing (RT-CES analysis)}

To perform the cytotoxicity assessment with the real-time cell analyzer, first $50 \mu \mathrm{L}$ of growth medium was placed into $96 \times$ eplate to get a steady impedance value. Then human liver cancer (Huh7) cells were inoculated into the 96× e-plate (1000-5000 cells/well). The attachment, spreading, and proliferation of the cells were monitored every $30 \mathrm{~min}$ using the RT-CES in a cell culture incubator. $24 \mathrm{~h}$ after seeding, cells were treated with $\mathrm{IC}_{100}$, $\mathrm{IC}_{50}$ and $\mathrm{IC}_{25}$ concentrations of the selected compounds. DMSO (AppliChem Biochemica, Darmstadt, Germany) was used as a negative control. Each experiment was repeated at least three times. 
The electronic readout (cell-sensor impedance) was displayed as an arbitrary unit called the cell index $(\mathrm{CI})$. The $\mathrm{CI}$ value was noted every $10 \mathrm{~min}$ for the first $24 \mathrm{~h}$ and then every $30 \mathrm{~min}$. The cell inhibition rate $(\%)=\left[1-\left(\mathrm{Cl}_{\text {treated cells }} / \mathrm{CI}_{\mathrm{DMSO}}\right)\right] \times 100$.

\subsubsection{Immunofluorescence staining with hoechst 33258 protocol}

Cells were seeded on coverslips in six-well plates. After an overnight incubation period, cells were treated with $10 \mu \mathrm{M}$ of compounds for $48 \mathrm{~h}$. To determine nuclear condensation by Hoechst 33258 (Sigma-Aldrich) staining, cells were fixed with $1 \mathrm{~mL}$ of cold methanol for $10 \mathrm{~min}$ after being washed twice with ice-cold $1 \times$ PBS. Then the samples were incubated with $1 \mu \mathrm{g} / \mathrm{mL}$ of Hoechst for $5 \mathrm{~min}$ in darkness. The coverslips were then rinsed with distilled water, mounted on glass microscopic slides using $50 \%$ glycerol, and examined under fluorescent microscopy $(40 \times)$.

\subsubsection{Fluorescence-activated cell sorting (FACS)-propidium iodide method}

Huh7 cell line was inoculated into $100-\mathrm{mm}$ culture dishes (300,000 cells/dish). After $24 \mathrm{~h}$, cells were treated with $10 \mu \mathrm{M}$ concentration of compounds for 24 -hour and 48 -hour periods. Then cells were trypsinized and collected as cell pellets, and samples were fixed in ice-cold $70 \%$ ethanol and stored at $-20^{\circ} \mathrm{C}$. Before the analysis, the samples were stained with $500 \mu \mathrm{L}$ propidium iodide solution according to the manufacturer's protocol. Cell cycle analysis was conducted with CellQuest Software.

\subsubsection{Oxidative stress assays}

Huh7 and Mahlavu cells were inoculated into 96-well 100-mm culture dishes. After $24 \mathrm{~h}$, they were treated with $10 \mu \mathrm{M}$ compounds, or DMSO control for $48 \mathrm{~h}$. Then cells were collected with trypsinization and samples were prepared according to MUSE Oxidative Assay kit (MCH100111, Millipore) manufacturer's protocol and analyzed. In parallel, cells were cultured into 6-well dishes and treated with the compounds or controls for $48 \mathrm{~h}$. Then, cells were washed with $1 \mathrm{xPBS}$ and stained with Dichloro-dihydro fluorescein diacetate (DCFH-DA) solution $(10 \mathrm{mM}$ glucose, $1 \mathrm{mM}$ DCFH-DA, $10 \mathrm{mM}$ HEPES dissolved in $1 \times$ PBS) for $15 \mathrm{~min}$, at $37^{\circ} \mathrm{C}$, in dark. Later, cells were washed three times with $1 \mathrm{xPBS}$ and observed under fluorescent microscope. In both experiments, one group of cells were grown in selenium deficient serum-free medium as positive control for oxidative stress. ${ }^{41}$

\subsubsection{Western blot experiments}

Huh7 and Mahlavu cells were treated with the compounds or with DMSO control for 24 or 48 h. 25 ng of protein was used per well (NuPAGE). p-Akt (Ser473) (9271, Cell Signaling), Akt (9272, Cell Signaling), p-GSK3- $\alpha / \beta$ (Ser21/9) (9331, Cell Signaling), GSK3- $\alpha / \beta$ (sc7291, Santa Cruz), SAPK/JNK (9252, Cell Signaling), pSAPK/JNK (Thr183/Tyr185) (4671, Cell Signaling), PARP antibody (9532, Cell Signaling) and p- $\beta$-catenin (sc57535, Santa Cruz), $\beta$ catenin (AB6300, Abcam), cyclin D1 (sc246, Santa Cruz), p-ASK1 (S83) (ab47304, Abcam) and p-ASK1 (S966) (ab39402, Abcam) antibodies were used in 1:100 to $1: 5005 \%$ BSA-TBS-T. Actin (Sigma, A5441), antibodies used for equal loading.

\subsubsection{COX activity assay}

Huh7 and Mahlavu cells were treated with the compounds or with DMSO control for $48 \mathrm{~h}$. $30 \mathrm{ng}$ of protein obtained from treated cells was used per well. For the assessment of the effect of the molecules on COX activity, Cyclooxygenase (COX) Activity Assay Kit (Fluorometric) (BioVision, K549-100) was used according to manufacturer's protocol. Experiment was conducted in duplicate.

\subsection{In silico analysis}

\subsubsection{QSAR}

The 2D molecular structures of the compounds were used to calculate mono- and bi-dimensional molecular descriptors, as well as PubChem molecular fragments, by the software PaDEL-Descriptors 2.18. ${ }^{54}$ Constant descriptors, and descriptors found to be correlated (correlation greater than 0.98 ) were discarded to minimize redundant information. A random $25 \%$ of the compounds were set aside as the test ('Prediction') set; the data split was conducted manually according to the structural similarity of the compounds so that both sets contained all structure classes and the training set contained the full range of activities. ${ }^{55}$ Rounds of Genetic Algorithm refinement of descriptor combinations were performed in QSARINS ${ }^{56}$ until the number of descriptors added to the model exceeded $1 / 5$ of the variables-this allowed for a maximum of 5 descriptors. An analysis of $R^{2}$ versus $Q^{2}$ revealed that all 5 descriptors improved the model, with $Q^{2}$ as well as $R^{2}$ improving with every addition of descriptor. The QUIK rule ${ }^{57}$ was applied to automatically exclude models where the correlation between the block of the descriptors and the response is lower than or too similar to the inter-correlation among the descriptors. A relatively stringent difference cutoff of 0.05 was set as recommended in the QSARINS manual. The models were also filtered according to the magnitude of the interval of confidence and significance of the model coefficients; a stringent confidence interval of 1.5 was set.

This initial first pass revealed that compounds Ibu, Nap, 1 and 2 were structural outliers (as determined by their leverage values being above the $h^{*}$ value or their predictions being above a residual threshold of 2.5). These compounds were excluded from both the training and test sets for the second run; the reduced number of datapoints meant that only 4 descriptors were included in the Genetic Algorithm (GA) refinement in order to keep to the 1:5 descriptors:variables limit. This time the $R^{2} / Q^{2}$ analysis revealed that only 3 descriptors were required to maximize $Q^{2}$. In addition, the confidence interval filter excluded all models with greater than 3 descriptors.

\subsubsection{Molecular docking}

Water molecules and other hetero atoms were removed and the program PDB2PQR $1.8^{58}$ was used to assign position-optimized hydrogen atoms, utilizing the additional PropKa ${ }^{59}$ algorithm with a $\mathrm{pH}$ of 7.4 to predict protonation states. The MGLTools 1.5 .4 utility prepare_receptor4.py ${ }^{60}$ was used to assign Gasteiger charges to atoms. Hydrogen atoms were assigned to ligand structures using OpenBabel 2.3.2 ${ }^{61}$, utilizing the $-\mathrm{p}$ option to predict the protonation states of functional groups at $\mathrm{pH}$ 7.4. The MGLTools utility prepare_ligand4.py ${ }^{60}$ was used to assign Gasteiger charges and rotatable bonds. A grid box that encompassed the maximum dimensions of the ligand plus $12 \AA$ in each direction was used. The starting translation and orientation of the ligand and the torsion angles of all rotatable bonds were set to random. The Autogrid grid point spacing was set at $0.2 \AA$. The Autodock parameter file specified 20 Lamarckian genetic algorithm runs, the number of energy evaluations as given by the equation $T^{2 *} 0.2627$ $+T^{*} 0.1551+0.2827$ (where $\mathrm{T}$ is the number of rotatable torsions in the molecule) and a population size of 300 . Autodock ${ }^{62}$ was used to automatically fit each compound into the active site of the receptor protein structure. PyMol 1.7.2.3 was used for visualization of the results and for figure generation.

\section{Acknowledgment}

This work was supported by The Scientific and Technological Research Council of Turkey under Grant \#112S211 and partially by Grant \#110S388. 


\section{Supplementary data}

Supplementary data associated with this article can be found, in the online version, at http://dx.doi.org/10.1016/j.bmc.2016.01.013.

\section{References and notes}

1. WCP World Cancer Report 2014. WHO Press, 2014.

2. Guadagni, F.; Ferroni, P.; Palmirotta, R.; Del Monte, G.; Formica, V.; Roselli, M. Anticancer Res. 2007, 27, 3147.

3. Greenspan, E. J.; Madigan, J. P.; Boardman, L. A.; Rosenberg, D. W. Cancer Prev. Res. 2011, 4, 161.

4. Kim, M. S.; Kim, J. E.; Lim do, Y.; Huang, Z.; Chen, H.; Langfald, A.; Lubet, R. A.; Grubbs, C. J.; Dong, Z.; Bode, A. M. Cancer Prev. Res. 2014, 7, 236.

5. Gupta, S. C.; Sung, B. Y.; Prasad, S.; Webb, L. J.; Aggarwal, B. B. Trends Pharmacol. Sci. 2013, 34, 508 .

6. Naruse, T.; Nishida, Y.; Hosono, K.; Ishiguro, N. Carcinogenesis 2006, 27, 584.

7. Amir, M.; Agarwal, H. K. Pharmazie 2005, 60, 563.

8. Abdelrahim, M.; Baker, C. H.; Abbruzzese, J. L.; Safe, S. J. Natl. Cancer Inst. 2006, 98, 855.

9. Grosch, S.; Tegeder, I.; Niederberger, E.; Brautigam, L.; Geisslinger, G. Faseb J. 2001, 15, 2742

10. Kulp, S. K.; Yang, Y. T.; Hung, C. C.; Chen, K. F.; Lai, J. P.; Tseng, P. H.; Fowble, J. W.; Ward, P. J.; Chen, C. S. Cancer Res. 2004, 64, 1444.

11. Lin, H. P.; Kulp, S. K.; Tseng, P. H.; Yang, Y. T.; Yang, C. C.; Chen, C. S.; Chen, C. S. Mol. Cancer Ther. 2004, 3, 1671.

12. Baris, D.; Karagas, M. R.; Koutros, S.; Colt, J. S.; Johnson, A.; Schwenn, M.; Fischer, A. H.; Figueroa, J. D.; Berndt, S. I.; Han, S.; Beane Freeman, L. E.; Lubin, J. H.; Cherala, S.; Cantor, K. P.; Jacobs, K.; Chanock, S.; Chatterjee, N.; Rothman, N.; Silverman, D. T. Int. J. Cancer 2013, 132, 162.

13. Cuzick, J.; Otto, F.; Baron, J. A.; Brown, P. H.; Burn, J.; Greenwald, P.; Jankowski, J.: La Vecchia, C.: Meyskens, F.; Senn, H. J.: Thun, M. Lancet Oncol. 2009, 10, 501.

14. Yao, M.; Zhou, W.; Sangha, S.; Albert, A.; Chang, A. J.; Liu, T. C.; Wolfe, M. M. Clin. Cancer Res. 2005, 11, 1618.

15. Tozkoparan, B.; Gokhan, N.; Aktay, G.; Yesilada, E.; Ertan, M. Eur. J. Med. Chem. 2000, 35, 743.

16. Tozkoparan, B.; Aktay, G.; Yesilada, E.; Ertan, M. Arzneimittel-Forsch. 2001, 51, 470.

17. Tozkoparan, B.; Aktay, G.; Yesilada, E. Farmaco 2002, 57, 145.

18. Tozkoparan, B.; Gokhan, N.; Kupeli, E.; Yesilada, E.; Ertan, M. ArzneimittelForsch. 2004, 54, 35.

19. Tozkoparan, B.; Kupeli, E.; Yesilada, E.; Isik, S.; Ozalp, M.; Ertan, M. ArzneimittelForsch. 2005, 55, 533.

20. Tozkoparan, B.; Kupeli, E.; Yesilada, E.; Ertan, M. Bioorg. Med. Chem. 2007, 15, 1808.

21. Tozkoparan, B.; Aytac, S. P.; Gursoy, S.; Aktay, G. Med. Chem. Res. 2012, 21, 192.

22. Aytac, S. P.; Tozkoparan, B.; Kaynak, F. B.; Aktay, G.; Goktas, O.; Unuvar, S. Eur. J. Med. Chem. 2009, 44, 4528 .

23. Tozkoparan, B.; Aytac, S. P.; Aktay, G. Arch. Pharm. 2009, 342, 291.

24. Tozkoparan, B.; Aytac, S. P.; Gursoy, S.; Gunal, S.; Aktay, G. Lett. Drug Des. Discov. 2012, 9, 204.

25. Khan, I.; Ibrar, A.; Abbas, N. Eur. J. Med. Chem. 2013, 63, 854.

26. D. Lauffer, A. Aronov, P. Li, D. Deininger, K. McGinty, D. Stamos, J. Come, M. Stewart, Preparation of fused triazoles as inhibitors of c-Met tyrosine kinase, W02007064797 2007.

27. Bhat, K. S.; Poojary, B.; Prasad, D. J.; Naik, P.; Holla, B. S. Eur. J. Med. Chem. 2009, 44,5066 .
28. Ibrahim, D. A. Eur. J. Med. Chem. 2009, 44, 2776.

29. D. Lauffer, P. Li, K. Mcginty, Aminopyrazole triazolothiadiazole inhibitors of cMet protein kinase, WO2010138665A1 2010.

30. Badr, S. M.; Barwa, R. M. Bioorg. Med. Chem. 2011, 19, 4506.

31. Sunil, D.; Isloor, A. M.; Shetty, P.; Satyamoorthy, K.; Prasad, A. S. B. Med. Chem Res. 2011, 20, 1074.

32. Zhao, P. L.; Duan, A. N.; Zou, M.; Yang, H. K.; You, W. W.; Wu, S. G. Bioorg. Med Chem. Lett. 2012, 22, 4471.

33. Khan, I.; Zaib, S.; Ibrar, A.; Rama, N. H.; Simpson, J.; Iqbal, J. Eur. J. Med. Chem. 2014, 78, 167.

34. Guven, E. B.; Aytac, P. S.; Cetin-Atalay, R.; Tozkoparan, B. Febs J. 2012, 279, 144

35. El-Serag, H. B.; Marrero, J. A.; Rudolph, L.; Reddy, K. R. Gastroenterology 2008 $134,1752$.

36. Thomas, M. J. Gastroenterol. 2009, 44, 136.

37. Aravalli, R. N.; Steer, C. J.; Cressman, E. N. Hepatology 2008, 48, 2047.

38. Metwally, K. A.; Yaseen, S. H.; Lashine el, S. M.; El-Fayomi, H. M.; El-Sadek, M. E. Eur. J. Med. Chem. 2007, 42, 152.

39. Vichai, V.; Kirtikara, K. Nat. Protoc. 2006, 1, 1112.

40. Adachi, M.; Sakamoto, H.; Kawamura, R.; Wang, W.; Imai, K.; Shinomura, Y. Histol. Histopathol. 2007, 22, 437.

41. Irmak, M. B.; Ince, G.; Ozturk, M.; Cetin-Atalay, R. Cancer Res. 2003, 63, 6707.

42. Amanatullah, D. F.; Reutens, A. T.; Zafonte, B. T.; Fu, M.; Mani, S.; Pestell, R. G. Front Biosci. 2000, 5, D372.

43. Maggiora, G. M. J. Chem. Inf. Model. 2006, 46, 1535.

44. Stumpfe, D.; Bajorath, J. J. Med. Chem. 2012, 55, 2932.

45. Theil, H. Economic Forecasts and Policy; North-Holland Pub. Co.: Amsterdam, 1961.

46. Todeschini, R.; Consonni, V. Molecular Descriptors for Chemoinformatics; Wiley vch, 2009 .

47. Burden, F. R. Quant. Struct-Act. Rel. 1997, 16, 309.

48. Randic, M. Math. Comput. Model. 1993, 17, 129.

49. Magnuson, V. R.; Harriss, D. K.; Basah, S. C. Studies in Physical and Theoretical Chemistry. In Chemical Applications of Topology and Graph Theory; King, R. B. Ed.; Elsevier: Amsterdam, 1983; pp 178-191.

50. Cherkasov, A.; Muratov, E. N.; Fourches, D.; Varnek, A.; Baskin, I. I.; Cronin, M. Dearden, J.; Gramatica, P.; Martin, Y. C.; Todeschini, R.; Consonni, V.; Kuz'min, V. E.; Cramer, R.; Benigni, R.; Yang, C. H.; Rathman, J.; Terfloth, L.; Gasteiger, J.; Richard, A.; Tropsha, A.; Modeling, Q. S. A. R. J. Med. Chem. 2014, 57, 4977.

51. Dearden, J. C.; Cronin, M. T. D.; Kaiser, K. L. E. SAR QSAR Environ. Res. 2009, 20, 241.

52. Leng, J.; Han, C.; Demetris, A. J.; Michalopoulos, G. K.; Wu, T. Hepatology 2003, $38,756$.

53. Ladu, S.; Calvisi, D. F.; Conner, E. A.; Farina, M.; Factor, V. M.; Thorgeirsson, S. S Gastroenterology 2008, 135, 1322.

54. Yap, C. W. J. Comput. Chem. 2011, 32, 1466.

55. Arnot, J. A.; Meylan, W.; Tunkel, J.; Howard, P. H.; Mackay, D.; Bonnell, M.; Boethling, R. S. Environ. Toxicol. Chem. 2009, 28, 1168.

56. Gramatica, P.; Chirico, N.; Papa, E.; Cassani, S.; Kovarich, S. J. Comput. Chem. 2013, 34, 2121.

57. Todeschini, R.; Consonni, V.; Maiocchi, A. Chemometr. Intell. Lab. 1999, 46, 13.

58. Dolinsky, T. J.; Czodrowski, P.; Li, H.; Nielsen, J. E.; Jensen, J. H.; Klebe, G.; Baker, N. A. Nucleic Acids Res. 2007, 35, W522.

59. Li, H.; Robertson, A. D.; Jensen, J. H. Proteins 2005, 61, 704.

60. Morris, G. M.; Huey, R.; Lindstrom, W.; Sanner, M. F.; Belew, R. K.; Goodsell, D. S.; Olson, A. J. J. Comput. Chem. 2009, 30, 2785.

61. O'Boyle, N. M.; Banck, M.; James, C. A.; Morley, C.; Vandermeersch, T. Hutchison, G. R. J. Cheminform. 2011, 3, 33.

62. Huey, R.; Morris, G. M.; Olson, A. J.; Goodsell, D. S. J. Comput. Chem. 2007, 28 1145 . 